\title{
Explaining the Varieties of Volunteering in Europe: A Capability Approach
}

\author{
Bernard Enjolras ${ }^{1}[$
}

Accepted: 8 March 2021/Published online: 5 April 2021

(C) The Author(s) 2021

\begin{abstract}
Volunteer rates vary greatly across Europe despite the voluntary sector's common history and tradition. This contribution advances a theoretical explanation for the variation in volunteering across Europe-the capability approach — and tests this approach by adopting a two-step strategy for modeling contextual effects. This approach, referring to the concept of capability introduced by Sen (Choice, welfare and measurement, Oxford University Press, 1980/1982), is based on the claim that the demand and supply sides of the voluntary sector can be expected to vary according to collective and individual capabilities to engage in volunteering. To empirically test the approach, the study relied on two data sources-the 2015 European Union (EU) Survey on Income and Living Conditions (EU-SILC), including an ad hoc module on volunteering at the individual level, and the Quality of Government Institute and PEW Research Center macrolevel data sets-to operationalize economic, human, political, social, and religious contextual factors and assess their effects on individuals' capability to volunteer. The results support the capability hypothesis at both levels. At the individual level, indicators of human, economic, and social resources have a positive effect on the likelihood of volunteering. At the contextual level, macro-structural indicators of economic, political, social, and religious contexts affect individuals' ability to transform resources into functioning - that is, volunteering.
\end{abstract}

Keywords Volunteering - Social origins - Capability . Europe $\cdot$ Multilevel analysis

\footnotetext{
Bernard Enjolras

bernard.enjolras@samfunnsforskning.no

1 Institute for Social Research, Oslo, Norway
}

\section{Introduction}

Despite sharing common philanthropic traditions and institutions, contemporary European countries display profound differences in their volunteer rates-that is, the share of a country's population involved in volunteering. Altruism and charity in Europe are rooted in shared medieval institutions and practices, especially religious ones (e.g. the Catholic Church). The modern voluntary sector emerged in most European countries during the eighteenth and nineteenth centuries in the wake of political transformations, including the rise of democratic institutions and popular movements (Harris et al., 2016). However, the continent today appears quite heterogeneous and diversified regarding the share of the population volunteering in a formal setting. Formal volunteering in Europe-measured according to the International Labour Organization (ILO, 2011) definition that emphasizes its organizational, unpaid, non-compulsory, and outside the family and kin characteristics-ranges from high rates in Nordic countries (50-30\% of the population volunteers) to low rates in Southern post-Communist countries (8-3\% of the population volunteers). How can such variations in volunteer rates be explained?

Researchers have emphasized that the social and institutional contexts in which people live are significantly associated with volunteering (Curtis et al., 2001; Ruiter \& De Graaf, 2006). However, a multidimensional theoretical explanation for how contextual factors of volunteering affect individual volunteering behaviours is lacking. The aim of this research is to advance the comparative study of determinants of volunteering by proposing a theoretical explanation for the variation in volunteering across Europe that integrates both contextual and individual factorsnamely the capability approach. To test this approach by 
modeling contextual effects, a two-step strategy was adopted that involved estimating two samples separately: the micro-level sample estimation produces micro-level effects, and the dependence of those effects on macro-level factors emerges from a second macro-level estimation.

\section{Theoretical Perspectives}

Figure 1 shows how greatly formal volunteer rates vary across Europe. How can these cross-national variations be explained? Answering this question will make a crucial contribution to our understanding of the forces underpinning the dynamism of civil society.

Looking beyond individual factors, the ways in which the larger sociocultural context or contextual factors impact volunteering is a matter that has received increasing attention over time. In their seminal contribution, Salamon and Sokolowski (2003) pointed out that the micro-structural approach to volunteering, which focuses on social capital and personal value systems, does not provide a good explanation for the differences in volunteer rates across countries. Macro-structural explanations for cross-national variations in volunteering are necessary to account for national patterns of individual behaviour. However, despite the multidimensional character of determinants of volunteering, the literature on comparative volunteering lacks an integrative multidimensional theoretical framework to inform empirical research. This literature has provided theoretical explanations that either are limited in terms of explanatory factors (mainly economic factors are central to the market/government failure, resource mobilization, and voluntary failure approaches) or, as in the case of the social origin approach, are difficult to test empirically with crosssectional data, since regime theories track historical institutional features to make causal inferences about the present, ignoring potential co-evolutionary patterns (Anheier et al., 2020). Thus, the purpose of the present study is to develop and test a multidimensional explanatory framework of cross-national differences in volunteering.

Salamon and Sokolowski (2003) identified four possible explanations in their examination of theories explaining cross-national variations in volunteering. The market failure/government failure theory (Weisbrod, 1977) sees volunteer action as a necessary response to the incapacity of the market and the government to satisfy heterogeneous
Fig. 1 Formal volunteering across Europe in percent of countries' population ( Source: author based on EU-SICL-2015 data)

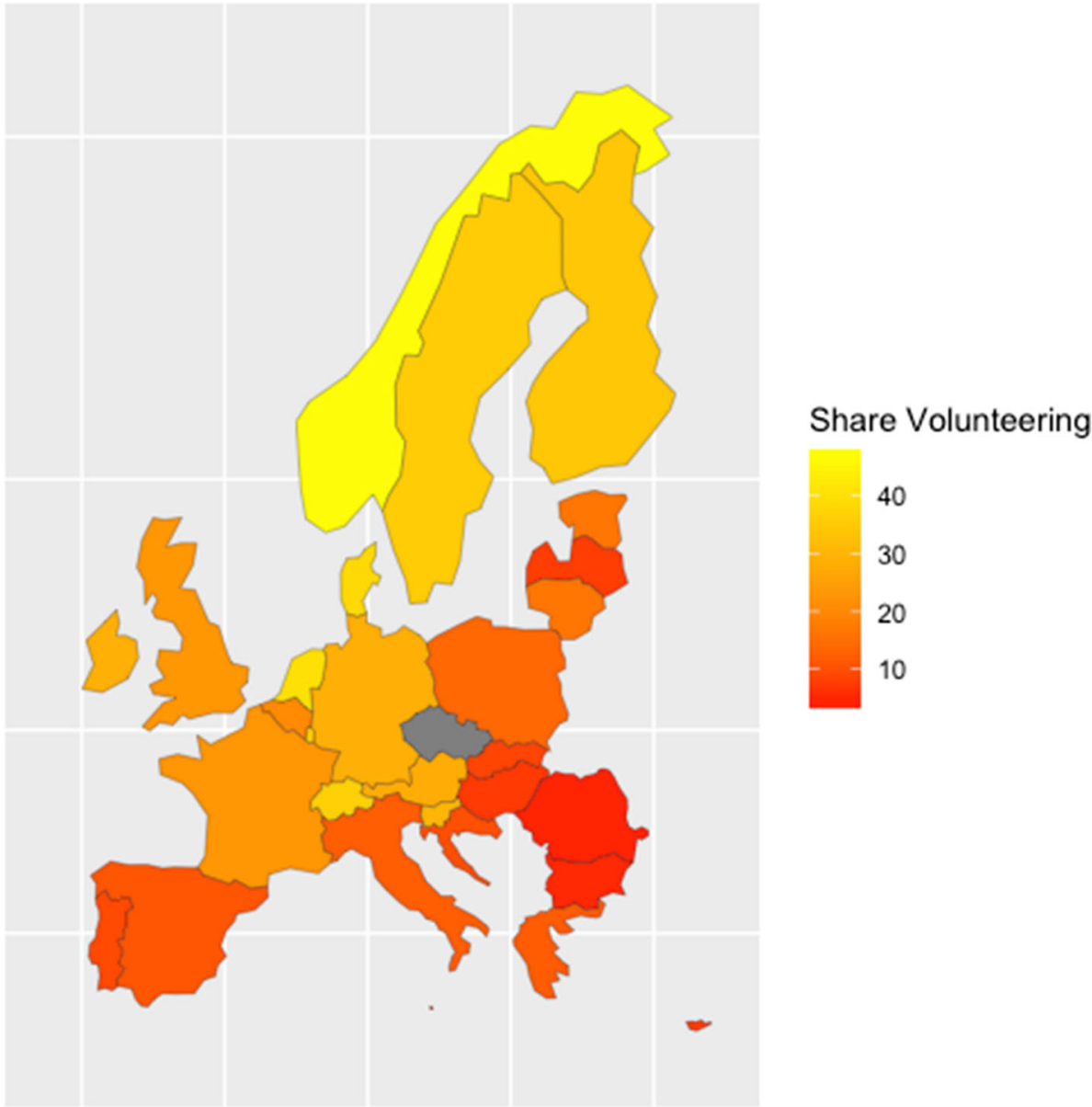


demands for collective goods. Voluntary failure/complementarity theory (Salamon, 1987) emphasizes interdependence and cooperative relations between the government and the voluntary sector as a result of the limitations inherent in voluntarism. The resource mobilization hypothesis underscores the availability of social and organizational resources for voluntary mobilization (McCarthy \& Zald, 1977) and articulates an entrepreneurial theory of the formation of civil society organizations where the major factor is the availability of resources, especially cadres and organizing facilities. The last explanation, privileged by Salamon and Sokolowski (2003) and labeled the social origins explanation (Salamon \& Anheier, 1998), emphasizes the institutionalization of power relations between social classes that have led to different types of welfare states and voluntary sector roles. The social origins theory explains the voluntary sector's size in terms of the factors determining the size of its workforce and its revenue base. These determining factors are, in turn, traced back to institutional features reflecting power compromises that once shaped different civil society models (liberal, social democratic, corporatist, and statist) and are characterized by the division of responsibility for the provision of quasi-public goods and services between the state, the market, and civil society. Each explanation provides a set of hypotheses relative to the relationship between government spending and the size and nature of the voluntary sector across countries that the above-cited authors tested empirically. However, these theories, as Steinberg and Young (1998) underlined, are not rival theories but complementary theories that explain more jointly than they do separately. These theories also have different explanatory scopes. As shown in Table 1, whereas social origins theory and the heterogeneity hypothesis aim at explaining why different institutional configurations structuring the opportunity structure of the voluntary sector appeared in the first place, the voluntary failure and resource mobilization approaches articulate some of the mechanisms through which these institutional configurations are sustained over time-that is, how, whether through resource mobilization or according to the degree of cooperation between the government and voluntary organizations, the division of labor between the market, the government, and the voluntary sector is maintained. The market failure/government failure explanation emphasizes economic mechanisms, while the social origins explanation relies on institutional mechanisms.

Additionally, as Ragin (1998) noted, social origins explanations involve a large variety of historical factors that combine in a unique fashion in each country and are, therefore, better suited to a qualitative approach for testing the theory - a fact that Salamon et al. (2017) seemed to acknowledge in their most recent attempt to provide support for the theory. Regime theories_-as far as regimes are specific institutional arrangements-look at whole configurations, emphasizing the conjunctions and interactions between civil society, the welfare state, and political and economic institutions. Whereas regression analysis requires that relationships between variables obey a common structure across countries, regime theory allows for different relationship patterns within each country, making it poorly suited for a quantitative analysis.

Recent empirical literature has further explored a range of mechanisms whose outcomes might contribute to different volunteer rates. These studies have investigated the cross-national macro-structural factors of volunteering, characterized by the adoption of quantitative methods for multilevel models that allow for investigating macrostructural factors and controlling for compositional differences due to the inclusion of individual-level variables. In a review of this literature, Baer et al. (2016) listed eight factors that have been mobilized to explain cross-country differences: welfare regime types, state involvement in the economy, ethnic heterogeneity, economic development, democracy, religiosity, cultural values, and trust.

European studies have adopted different theoretical perspectives and modeling strategies. Plagnol and Huppert (2009) concluded from their analysis of 2006 European Social Survey data that national differences in volunteer rates cannot be fully explained by differences in individual social, psychological, or cultural factors associated with volunteering, and thus, it is likely that contextual factors largely determine volunteer rates. However, how much such contextual factors account for this difference remains an open question. Gil-Lacruz et al. (2016) sought to identify the underlying reasons for differences in youth volunteer rates across Europe. They combined individual with national contextual data from the European Values Study in a cross-sectional study of 20 European countries and estimated a logistic regression including the individual and

Table 1 The four theoretical explanations of cross-country variation in volunteer rates compared

\begin{tabular}{lll}
\hline & Why different institutional configurations? & How different institutional configurations are sustained? \\
\hline Economic factors & Market/government failure & Resource mobilization \\
Institutional factors & Social origins & Voluntary failure/complementarity \\
\hline
\end{tabular}


contextual variables with dummies for each type of welfare regime. They concluded that macro-structural factors, such as welfare systems, by influencing government expenditures and employment, impact youth volunteering decisions. In another publication, the same authors (Gil-Lacruz et al., 2017) used three waves of the European Values Study and found that differences in volunteering participation rates could not be fully explained by individual characteristics, and they emphasized the significance of contextual factors. However, they employed as contextual variables the size of a residential area, the mean of other people's attitudes, and the mean of trust in institutions without providing a clear theoretical rationale for this selection of variables. Using four waves from the European Values Study, Damian (2018) examined cross-sectional and longitudinal effects of contextual cultural and economic characteristics of individual formal volunteering. The study considered cultural and economic explanations and assessed the effects of the following contextual factors on volunteering: religiosity, religious denomination, economic development, and income inequality. The results showed that church attendance had a negative effect on formal volunteering and lower inequality was positively associated with formal volunteering, indicating that people in secular and equal countries engage more in formal volunteering. In sum, the results of this literature have been mixed and often dependent on empirical specifications of macro-structural variables, as far as each contribution has focused on certain explanatory factors to the exclusion of others. Common to these studies, however, is that they tested for contextual economic, cultural, and institutional predictors of volunteering but did not build an integrative theoretical framework relating these explanatory factors to each other. Explaining cross-national differences in volunteering requires a general theoretical frameworktestable with quantitative means and enabling the integration of multiple factors into a coherent explanatory model - to guide the empirical investigation. The next section outlines such a framework based on the idea of capability.

\section{The Capability Approach}

Clearly, as noted in the social origins approach, institutional factors play a central role in explaining variations of volunteer rate across countries. However, this theoretical approach is difficult to test empirically because it lacks parsimony and because the long timeframe and complexity of factors that the approach identifies make it difficult to disentangle historical from present factors (Anheier et al., 2020). Additionally, economic, political, social, and cultural factors play a role in determining variations of volunteer rates. The theoretical understanding advanced here, first, operates takes into account institutional variations across civil society regimes (as identified by the social origins approach). Different institutional regimes can be expected (as they relate to different patterns of redistribution and social security, different qualities of civil liberties, pluralism, and the rule of law) to generate different sets of capabilities that, in turn, impede the volunteer rate. Second, the capability approach aims to provide an encompassing framework integrating different factorseconomic, political, cultural, and social-that diverse existing theories emphasize separately. Third, the capability approach allows for bridging the micro-macro-link and agency-structure relation within a coherent theoretical framework. Indeed, volunteering is seen as the result of individual agency (choice and action) conditioned on the capability to volunteer (agency-structure relation) and of individual as well of contextual factors (micro-macrolink). This capacity to transform resources into functioning is, in turn, influenced by contextual structures-namely "material and ideal constraints to the context that provides the conditions of existence of specific interactions" (Layder, 1981, p. 96).

A way to integrate multiple explanatory factors at the micro- and macro-structural levels is to consider the amount of volunteering in each country as reflecting citizens' propensity to voluntarily engage in the creation (entrepreneurship), maintenance, and operation of voluntary organizations. Thus, the total amount of volunteering is the combined result of the demand for volunteering (i.e. existing voluntary organizations and entrepreneurship initiatives, both individual and collective) and the supply of volunteer work (i.e. individuals willing to do non-paid work in different capacities for given purposes).

From this perspective, cross-country differences might be attributed to factors that affect the supply and demand of volunteer work. Concerning the supply of volunteering, these factors have been thoroughly studied at the microindividual level (Wilson \& Musick, 2008). At the microlevel, determinants of volunteering seem to be conditioned on individual levels of human, economic, social, and cultural capital, because volunteer work is productive work that requires human and economic capital, collective behaviour that requires social capital, and ethically guided action that requires cultural capital (Wilson \& Musick, 1997). However, at the micro-individual level, these forms of capital are influenced by macro-structural features that impact their availability and distribution in each country. In contrast, the demand for formal volunteering is influenced by the size and sustainability of the population of voluntary organizations enrolling individuals in activities that require volunteer work as well as the dynamics of creating new organizations. The size of the existing population of 
voluntary organizations, their activity levels, and the dynamics of their creation are, in turn, determined by a range of economic, political, social, and cultural factors that set the conditions for collective and individual civil society entrepreneurs and leaders to create and sustain voluntary organizations.

The claim is that the supply of voluntary work can be expected to vary accordingly to individual capabilities to engage in volunteering. The concept of capability introduced by Sen $(1980 / 1982,1985,1992)$ is defined as "set of vectors of functionings, reflecting the person's freedom to lead one type of life or another" (Sen, 1992, p. 40). Functionings, in turn, consist of beings and doings, constitute the basis of living, and range from basic things, such as good health, to complex achievements, such as selfrespect and happiness. Closely related is the concept of capability to function - a set of functionings - reflecting a person's freedom to choose among valuable functionings to achieve well-being. Nussbaum (2000) provided a list of central human capabilities, including life, bodily health, bodily integrity, sense of imagination and thought, emotions, practical reason, affiliation, other species, play, and control over one's environment (political and material). Thus, the concept of capability is very broad-including all dimensions of life-and provides an alternative method to utility or basic goods for assessing well-being and inequality. More importantly, for our purpose, the concept of capability relates the availability of resources and structural conditions (the means of freedom) to the ideas of choice and freedom. Volunteering is, as its etymology indicates, a free or voluntary action, but integral to freedom of action are the means of freedom-that is, the individual and collective resources and conditions that allow free choice and, in the case of volunteering, social cooperation. Voluntary action may be considered a capability that is strongly related to three capabilities identified by Nussbaum (2000): control over one's political and material environments and affiliation.

Then, the concept of capability, although broad, is related to the concept of capital insofar as it includes the idea that the availability of individual and collective resources (capital) is decisive in explaining different forms of inequality, including inequality in engagement in volunteer work. In economic terms, capital is a stock that has value as a source of current and future flows of output and income. The principles of capital theory were extended first to human capital (Becker, 1963/1993) — the stock of skills and productive knowledge embodied in people-and then to cultural and social capital (Bourdieu, 1986). According to Bourdieu (1986), capital exists in three fundamental forms: "as economic capital convertible into money and institutionalized in the form of property rights, as cultural capital institutionalized in the form of educational qualification and as social capital made up of social obligations (connections)" (p. 16). These forms of capital not only benefit the individual who "owns" the capital; as Coleman (1988) indicated, social capital, economic capital, and cultural capital all have a public good aspect, meaning that they benefit everyone who is part of the social structure in which these forms of capital function. The concept of capability, thus, encompasses the concept of capital insofar as it is concerned with the means of freedom, or the resources that enable individual action, but add to it a dimension of agency, as the resources or forms of capital seen as enabling the individual's free choice are the conditions for freedom and choice. As Sen (1997) emphasized, if notions of human and social capital are related to the idea of capability, the concept of capability is not an alternative to that of capital but a broader perspective that focuses "on the expansion of human freedom to live the kind of lives that people have reason to value" (p. 1960). In short, the difference between capability and capital is homologous to the difference between ends and means. A capability is "a person's ability to do valuable acts or reach valuable states of being; [it] represents the alternative combinations of things a person is able to do or be" (Deneulin et al., 2006, p. 2). Thus, capabilities encompass resources and forms of capital, as they enable individuals to freely choose the pursuit of valuable finalities, as well as the dimension of choice and freedom.

By emphasizing freedom and choice, the capability approach allows for bridging the micro-macro-gap, linking individual choices to macro-level conditions. Indeed, individual capabilities are not only dependent on individual resources and forms of capital but also on macro-structural features that enable or limit both choice and action. Thus, the capability of volunteering - the individual choice and functioning actualized in doing volunteer work-is dependent on individual resources or forms of capital (converted into functionings) and macro-structural features that enable or limit this choice and functioning.

The capability approach does not contradict but complements the social origins theory of the voluntary sector. Institutions and capabilities are related, since institutions are both constraints to, and enablers of, individual agency-in Sen's terminology, the conversion of capabilities into functionings, or beings and doings (Nambiar, 2013). Different civil society regimes can be regarded as producing different conditions, enabling more or less individual capability and functioning for volunteering, thereby influencing the supply and demand of volunteering. Whereas the social origins theory examines the institutional-structural characteristics of each country-specific civil society and assesses how these characteristics generate different patterns of volunteering, the capability approach to volunteering is located at a lower explanatory 
level and focuses on the factors that, given the institutionalstructural features of civil society, influence the supply and demand of volunteering. Different welfare state and civil society regimes can be expected to generate different sets of capabilities, enabling individuals to engage more or less in the voluntary sector. Furthermore, different forms of individual capital (human, economic, and social capital) and contextual features in the economic, political, cultural, and social realms, relating to different institutional welfare state and civil society regimes, can be expected to condition individuals' capability to engage in volunteering.

Volunteering is a functioning, and we observed only functionings. The capability approach to volunteering asserts that volunteering (functioning) is dependent on the capability to volunteer-that is, an individual's ability to convert resources into functioning according to freely chosen valued finalities. The availability of both microlevel resources and macro-structural features shapes this capability. This perspective allowed us to formulate the following hypotheses linking resources, macro-structural features, and functionings.

In sum, the idea of capability has a subjective dimension (the free choice of ends) and an objective dimension (the conditions enabling this free choice). Capabilities are transformed into functionings i.e. actions. What we observe is not the capability per se, but the action (functioning) of volunteering. Institutional factors (including the individual distribution of different forms of capital) influence the objective dimension of the capability to volunteer (the conditions of free choice) and consequently the ability to act (functioning). Compared to existing approaches, the capability approach provides a coherent theoretical framework for linking individual-level resources and macro-level institutional features that shape the capability to volunteer.

Hypotheses From the viewpoint of the capability approach, volunteering as a functioning depends on individuals' freedom to choose volunteering as a valued activity and identity, and this freedom is conditional on the availability of resources or forms of capital and the social structures and institutions shaping the context of their choice. Therefore, we tested the following hypotheses linking volunteering to forms of capital at the individual level and macro-structures at the contextual level.

\section{Individual-Level Hypotheses}

H1 Individual forms of capital are positively associated with volunteering.

Following Wilson and Musick (1997), individuals' supply of volunteer work is dependent on individuals' possession of three forms of capital: human, social, and cultural capital. To those forms of capital, one can add economic capital (Bourdieu, 1986). The possession of these forms of capital constitutes a capability for volunteering insofar as it can be converted into the functioning of volunteering. More specifically, the following relationships can be expected.

H1-1 Individual human capital is positively associated with volunteering.

Human capital relates to resources attached to individuals that enable productive activities. Variations in human capital explain individual differences in labor force participation, productivity, and reward. As far as human capital affects job participation and performance in the labor market, it pertains to a type of resource (knowledge, skills, health) that influences individuals' capacity to do volunteer work.

H1-2 Individual economic capital is positively associated with volunteering.

Economic capital constitutes another resource that influences the capacity to volunteer. From an economic perspective, the voluntary labor supply, understood according to the mechanisms characterizing paid labor, is bound by a paradox: individuals with high earning capacity and, consequently, higher opportunity costs (losing more income by choosing free time) are more likely to volunteer than those with low earning capacity, whose free time is less valuable (Freeman, 1997). This paradox is due partly to two effects-income and substitution effects-linked to individuals' decisions about how much of their time they will allocate to paid work versus free time (including volunteering). People with higher incomes are likely to display a negative substitution effect-preferring free time to increased income-despite displaying a positive income effect (increased income due to increased time allocated to paid work).

H1-3 Individual social capital is positively associated with volunteering.

Social capital encompasses resources that are dependent on social connections and personal networks (information and trust) that make cooperation and volunteering more likely (Putnam, 1993, 1995a, 1995b).

\section{Country-Level Hypotheses}

H2 The more prosperous the country (measured by GDP), the higher the volunteer rate.

A country's level of economic prosperity, in addition to individual economic resources, might contribute to shaping individuals' capability to volunteer. Lancee and Van de 
Werfhorst (2012) showed that individuals' economic resources have a positive impact on their civic participation. The economic resource explanation has been extended to the community level, stipulating a negative association between country-level resources (lack of financial support) and volunteering.

H3 The greater the income inequality in a country, the lower the volunteer rate.

The degree of inequality characterizing a country might contribute to shaping individuals' capability to volunteer. From a theoretical standpoint, explanations for the relationship between socioeconomic inequality and volunteering are ambiguous (Schröder \& Neumayr, 2019), with the sociological literature identifying a negative relationship and the economic literature pointing to a positive relationship. Indeed, several mechanisms might contribute to this relationship between economic inequality and participation (Schröder \& Neumayr, 2019). First, as Lancee and Van de Werfhorst (2012) showed, the main effect of inequality on civic participation manifests via individual resources. However, independent of the level of individual resources (when controlling for individual income), higher inequality at the country level appears to have a negative effect on participation. However, studies that extensively controlled for the effects of contextual- and individuallevel resources have established that differences in economic resources are insufficient in accounting for differences in participation (Alesina \& La Ferrara, 2000), pointing to other explanatory mechanisms. One such explanatory mechanism emphasizes the correlation between socioeconomic inequality and social integration: socioeconomic inequality undermines social cohesion, solidarity, and trust (Uslaner \& Brown, 2005) and can be expected to exert a negative effect on volunteering. In contrast to explanations identifying a negative effect of socioeconomic inequality on civic participation, the inequality aversion hypothesis (Anderson et al., 2008) points to a positive effect of inequality on volunteering, inasmuch as inequality may trigger individuals with altruistic preferences to increase their voluntary contribution. However, the capability hypothesis predicts a negative effect of socioeconomic inequality on volunteering, either through resource deprivation or lack of social cohesion.

H4 Political liberties enhance individuals' capability to volunteer and are expected to be positively associated with volunteering.

Voluntary organizations and volunteering are contingent on their political and institutional contexts. Rights and liberties shape the institutional space of freedom that the state grants to civil society. Kamerāde et al. (2016) examined the relationship between civil liberties and volunteering in six former Soviet Bloc countries and found evidence that it is not volunteering that brings civil liberties but that increased civil liberties lead to higher volunteer rates.

H5 High levels of social trust enhance individuals' capability to volunteer and are expected to be positively associated with volunteering.

Social trust, or the expectation that others will behave with goodwill and that they intend to honor their commitments, may facilitate volunteering not only as an individual attitude but also as a contextual factor. Social trust facilitates cooperative endeavors and has the character of a public good benefiting all members of a community. For this reason, it can be expected to enhance volunteering capability. Glanville et al. (2016), for example, showed that contextual trust levels are positively related to volunteering because social capital exists at different levels of the social structure, including groups and communities. Others have emphasized that high levels of social trust must be attributed to the role of the welfare state and redistribution. Although some authors have focused on low levels of social inequality (Bjørnskov, 2006; Delhey \& Newton, 2005; Uslaner, 2003), others have viewed state institutions and the rule of law as crucial forces fostering generalized trust in society (Rothstein, 2001). Rothstein and Stolle (2008), for example, argued that the state has a particular role in generating trust by sustaining values such as impartiality, equality before the law, respect for human rights, equal opportunity, and efficiency. According to these authors, it is the quality of the rule of law that has the strongest bearing on generating trust among citizens.

H6 High levels of country religiosity are expected to enhance the capability to volunteer, because religiosity increases accessibility to volunteering opportunities due to increased density in networks of volunteers.

As Hustinx et al. (2015) clarified, two major mechanisms predict a positive relationship between religion and volunteering: religious beliefs and religious practice. Religious beliefs entail a valuation of altruism that can be expressed in volunteering, and religious practice (attendance of religious services) generates social networks that serve as important recruitment channels for volunteering. According to Kelley and De Graaf (1997), the countrylevel degree of religiosity influences volunteering on behalf of non-religious individuals through the interactive effect of exposure to religious (altruistic) culture and social networks. However, "the hypothesis of a harmonious causal relationship between religion and volunteering" (Hustinx et al., 2015, p. 2) is under tension because of the changing role of religion in society and the process of secularization. As Ruiter and De Graaf (2006) pointed out, in devout 
countries, individuals' social networks contain a larger number of religious people, who may introduce them to volunteering opportunities. The increased density of altruistically oriented individuals in social networks, thus, can be expected to enhance an individual's capability to volunteer. However, this relationship has been contested on both theoretical and empirical grounds (Bennett, 2015). Additionally, religious diversity-often measured in terms of religious fractionalization (Alesina et al., 2003) - may increase the likelihood of volunteering (Borgonovi, 2008) by fostering competition between religious groups.

\section{Data, Measurements, and Method}

In this work, an empirical strategy was designed to assess the effect of macro-structural factors given individual-level differences. For this purpose, a multilevel model was estimated. The capability approach entails that individual and contextual factors influencing individuals' means of freedom and, consequently, capabilities to volunteer will be correlated with a country's volunteer rate. These factors are related to economic, human, and social capital as well as political factors that shape individuals' ability to participate in civil society. However, there are many ways to empirically operationalize such concepts as economic, human, and social capital and political opportunity structures at the individual and contextual levels. Additionally, the choice of empirical indicators is constrained by the availability of comparative data and the necessary parsimony of the model at level two of analysis. Furthermore, the number of variables included at the two levels of analysis is constrained by the size of the country sample. With data available for 23 countries, only a few contextual variables could be used in each model. Therefore, imperfect indicators of the main capability dimensions-economic, social, and political-were selected for the two levels of estimates. In what follows, the data and variables used at both levels are described.

\section{Data and Samples}

The analysis of factors influencing volunteering levels in Europe relied on two data sources. At the individual level, we used data from the 2015 EU Survey on Income and Living Conditions (EU-SILC) including an ad hoc module on volunteering. These data were documented in Eurostat (2016) and constitute the EU reference source for comparative statistics on income distribution and social exclusion in Europe. Each year, the survey includes different specialized modules, and in 2015, one ad hoc module was devoted to social and cultural participation, including volunteering. The reference population of EU-SILC is private households and their current members residing in the territory of the member states at the time of data collection. Persons living in collective households (e.g. boarding houses, dormitories at educational institutions, etc.) and institutions are generally excluded from the target population. The cross-sectional component has a minimum sample size of 106,000 households representing EU member states plus Iceland and Norway. All persons over 16 years old were interviewed in each household, giving a sample of 310,150 persons in the 26 EU countries in 2015 (23 EU member states plus Iceland, Norway, and the Former Yugoslav Republic of Macedonia [FYROM]). Individual sample weights provided by Eurostat were used to obtain a representative sample of the population in each country.

At the macro-level, we used data collected by the Quality of Government Institute (QoG) and documented by Teorell et al. (2019) and the PEW Research Center. The QoG data set is composed of data compiled at the country level (including aggregated individual data), drawing on several freely available data sources and comprises more than 2,000 variables. The 2019 version of the QoG data includes data from and around 2015. If no data for 2015 existed, data for 2014 were included, and so on, up to a maximum of $+/-3$ years. The cross-country data include 35 countries that were members of the Organisation for Economic Co-operation and Development (OECD) at the end of 2018. The data on religion come from two surveys administered by the PEW Research Center in 2015 and 2017, respectively, in Eastern Europe (survey conducted between June 2015 and July 2016) and Western Europe. Matching the EU-SILC data with the QoG data and PEW data yielded a data set of 23 countries available for the two-level analysis, as not all 25 countries included in the EU-SILC data set are in the QoG data set.

\section{Variables at the Individual Level}

The outcome variable of interest is a measure of formal volunteering - that is, volunteering performed within the framework of an organization. The EU-SILC survey asks respondents whether they have participated in formal volunteer work during the previous 12 months. Possible answers are Yes; No, lack of interest; No, lack of time; and No, other reason. The variable was coded into a dichotomous variable, Yes/No. The main advantage of using the $2015 \mathrm{EU}$ SILC survey for measuring volunteering is, first, the quality of data in terms of cross-country comparability, common methodology implemented by 25 European countries under the auspice of Eurostat, and a large sample size for each country. However, the formulation of the question concerning volunteering (as a Yes/No answer referring to the 
previous 12 months) presents some shortcomings compared to other data sources. In contrast to the recommendations of the ILO (2011), the EU-SILC survey does not implement prompting to assist respondents. The high "buffering" prompting recommended by the ILO manual consists of an extensive series of Yes/No questions about specific volunteer activities in which the respondent may have participated and then asks the respondent for details about each activity. Additionally, the EU-SILC survey employs a 12-month reference period during which the respondent may have volunteered, with the risk of lower accuracy of recall compared to the four-week reference period recommended by the ILO manual. However, there are also some benefits of using a 12-month reference period. For instance, the four-week period can capture time-of-year effects, such as specific (religious) holidays, during which people volunteer more often.

We used two variables to capture differences in human capital: Education, measured in terms of the highest International Standard Classification of Education (ISCED) level attained (ranging from $0=$ pre-primary education to $6=$ the second level of tertiary education), and selfassessed General health (ranging from $1=$ very bad to 5 = very good).

Number of hours usually worked per week in the main job was used for considering, in combination with income level, the substitution effect between free time and working time. Additionally, different forms of economic capital, and especially income levels, were considered indicators of social status that are positively associated with volunteering, as wealthy individuals are three times more likely to be asked to volunteer (Hodgkinson, 1995). Therefore, income was measured by Household income rather than the respondent's personal income, because household income is considered a better indicator of social status. Another indicator of social status was the individual's Employment status, measured by a dummy variable indicating whether the individual was fulltime employed (1) or had another status (0), including inactive, retired, unemployed, student, and part-time employed.

At the individual level, social capital was measured by two indicators-Frequency of contact with friends and Number of children in the household-assuming that people who report frequent contact with friends and parents of children still living in the household have more social contacts and are more likely to volunteer.

At the individual level, three demographic factors that might affect individual volunteering rates were considered: Marital status (never married, married, separated, widowed, divorced, or consensual union), Gender, and Age. Marital status might influence the social integration of individuals within the community and, consequently, the likelihood of volunteering. We expected gender differences in volunteering especially in countries with higher gender inequality, because traditional gender roles socialize men and women into different patterns of participation in the public sphere. Age was expected to affect the likelihood of volunteering inasmuch as obligations and responsibilities vary across the lifetime.

A logistic regression model at the individual level (step 1) of analysis was estimated for each country with the dichotomous variable of participation in formal volunteering as the dependent variable and the following independent variables: marital status, education, gender, health, economic status, weekly hours worked, household disposable income, age, number of children living in the household, participation, and frequency of contact with friends. We now turn to the description of variables at the contextual level (step 2) of analysis.

\section{Variables at the Contextual Level}

At the contextual level (second level), the variables used in the analysis were chosen for their ability to operationalize relevant dimensions of the two theoretical approaches to be tested. The capability approach predicts positive associations between cross-national volunteer rates and indicators of democracy, social equality, and trust, whereas the failure approach predicts a positive association between heterogeneous preferences and volunteering. These indicators are described in detail as follows.

\section{Contextual Indicators of Economic Structures}

Economic structures were approximated using two variables. GDP per capita from the OECD database was used to measure the relative wealth of countries, whereas income inequality was measured with the OECD Gini index. The Gini index is a measure of statistical dispersion intended to represent the income or wealth distribution of a country's residents, and it is the most commonly used measurement of inequality. A Gini coefficient of zero expresses perfect equality, whereas a Gini coefficient of one expresses maximum inequality.

\section{Contextual Indicators of Political Structures}

Political structures were operationalized through two variables. The first variable, provided by Freedom House, which conducts an annual comparative assessment of political rights and civil liberties covering 195 countries, ${ }^{1}$ is an indicator of Political pluralism and participation. This variable encompasses an examination of the people's right to freely organize in political parties; the existence of an opposition with a realistic possibility of increasing its

\footnotetext{
${ }^{1}$ https://freedomhouse.org/report-types/freedom-world.
} 
support; the ability of the people to make political choices free from domination by the military, totalitarian parties, or other powerful groups; and the existence of full political rights for all minorities. Countries are graded from 0 (worst) to 16 (best). The second variable, provided by Sustainable Governance Indicators (SGI), a platform built on a cross-national survey of governance that identifies reform needs in $41 \mathrm{EU}$ and OECD countries, is an indicator of Civil rights and political liberties. Civil rights and political liberties allow for the freedoms of expression and belief, associational and organizational rights, the rule of law, and personal autonomy without interference from the state. Countries are graded from 1 (worst) to 10 (best).

\section{Contextual Indicators of Social Structures}

Contextual indicators of social structures were selected to capture features of the social structure that enhance cooperation and voluntary engagement. The Social trust variable was obtained from Human Understanding Measured Across National (HUMAN) surveys. This data source combines multiple sources of public opinion data and creates commonly formatted variables. This data set provides country survey data, meaning that each observation is an aggregated score representing all respondents within a country for a survey round. Thus, the variable Social trust is an index of multiple surveys. The index score represents an average of all country survey scores available within each country-year observation. Scores range from 0 , representing the lowest possible level of trust, to 100 , representing the highest possible level.

We approximated the quality of rule of law using Freedom House's Rule of law variable. The variable measures the independence of the judiciary; the extent to which the rule of law prevails in civil and criminal matters; the existence of direct civil control over the police; protection from political terror, unjustified imprisonment, exile, and torture; absence of war and insurgencies; and the extent to which laws, policies, and practices guarantee equal treatment of various segments of the population. Countries are graded between 0 (worst) and 16 (best).

\section{Contextual Indicators of Religiosity}

At the contextual level, religiosity may influence individuals' capability to volunteer. Three variables were used to control for different dimensions of religiosity, including the level of religious fractionalization (measuring religious heterogeneity), the degree of religious freedom, and the importance of religion in a country. The two first variables, religion fractionalization and freedom of expression and belief, were obtained from the QoG data set. Religion fractionalization is an index reflecting the probability that two randomly selected people from a given country will not belong to the same religious group. The higher the number, the more fractionalized the society. Freedom of expression and belief was operationalized using a composite index elaborated by Freedom House that measures the freedom and independence of the media and other cultural expressions; the freedom of religious groups to practice their faith and express themselves; academic freedom and freedom from extensive political indoctrination in the education system; and the people's ability to engage in private (political) discussions without fear of harassment or arrest by the authorities. Countries are graded between 0 (worst) and 16 (best).

The instrument for measuring the Importance of religion in a country was provided by two surveys conducted by PEW Research Center in 2015 and 2017, respectively, in Eastern Europe (survey conducted from June 2015 to July 2016) and Western Europe (survey conducted in April-August 2017). In both surveys, respondents were asked "How important is religion in your life?" with possible answers of Very important, Somewhat important, Not too important, or Not at all important. A dummy variable was coded 1 if the respondent answered Very important or Somewhat important and 0 otherwise. For each country, the variable Importance of religion was the weighted mean of the dummy variable.

\section{Statistical Method}

Multilevel (or mixed effects) models are an extension of simple linear models that allow both fixed and random effects, and they are particularly used when there is nonindependence in the data, which can arise from a hierarchical or multilevel structure. Multilevel models can be thought of as a trade-off between (i) aggregating individual observations at the unit (country) level and (ii) analyzing data from one unit at a time. The individual regressions have many estimates and considerable data, but they are prone to high margins of error (statistical "noise" or estimation error). The aggregate is less characterized by estimation error, but may lose important differences when all samples within each unit are averaged. Additionally, multilevel modeling is suitable for investigating contextual effects. Multilevel modeling with two levels (individual and country levels) was implemented in this study in a twostep estimation procedure to investigate macro-contextual influences on individual volunteering. This two-step approach consists of one regression at the individual level and one regression at the country level (Borjas \& Sueyoshi, 1994; Card, 1995; Hanushek, 1974; Saxonhouse, 1976; a special issue of Political Analysis introduced by Kedar \& Shively, 2005). In the first step, one fits, for each country, the individual-level model using a logistic regression. 
Country-level effects are ascertained from the second step in which the fitted country intercepts from step 1 are regressed on the country-level predictors. A two-step procedure presents several advantages compared to a simultaneous estimation. First, it offers more flexibility in modeling individual-level specifications for each country without loss of efficiency (Jusko \& Shively, 2005). Second, simultaneous multilevel models that assume a multivariate normal distribution of error terms do not converge when the data structure is complex (Franzese, 2005). Finally, the results of the estimation are easy to display graphically, facilitating the interpretation of results.

As Bryan and Jenkins (2016a) emphasized, the two-step procedure gives unbiased estimates of individual- and country-level coefficients, and the procedure produces correct standard errors. Moreover, the ordinary least square in step 2 provides an unbiased estimate of the variance of country effects $\left(\sigma^{2}\right)$. These properties apply even if there are few countries (Bryan \& Jenkins, 2016a). An issue related to the two-step method, which applies more generally to estimation using clustered data, is that the estimation of country-level predictors is based on a limited number of observations (number of countries), entailing that the variance of the country-specific effect $\left(\sigma^{2}\right)$ is likely to be estimated imprecisely with a small number of countries. Monte Carlo simulations based on empirical distributions of variables in the 2007 EU-SILC data indicated that the two-step model performs well with 25 countries (Bryan \& Jenkins, 2016b) and that country-level fixed parameters are likely to be estimated imprecisely with a small number of countries (around 10).

Additionally, as estimate parameters from the first step were used as dependent variables in the second step, an estimated dependent variable (EDV) correction with a feasible generalized least square, as suggested by Lewis and Linzer (2005), was implemented using the R script that fits the feasible generalized least square (FGLS) models described in Lewis and Linzer (2005). This EDV correction accounts for uncertainties stemming from the first-step estimation and the macro-level error term from the second-step regression.

The model estimated here, for individuals $i=1 \ldots . . n$, and countries $j=1 \ldots J$, can be written as follows:

Level 1

$y_{i j}=\beta_{0 j}+\beta_{1 j} x_{i j}+\varepsilon_{i j}$.

Level 2: Estimated intercept (varying intercept by country)

$\beta_{0 j}=\gamma_{00}+\gamma_{01} Z_{j}+\mu_{0 j}$.

Level 2: Estimated coefficients as dependent variable in level 2 (varying slope with constant intercept)

$\beta_{1 j}=\gamma_{10}+\gamma_{11} Z_{j}+\mu_{1 j}$.

\section{Full model}

We substitute to obtain a single-equation form:

$y_{i j}=\left(\gamma_{00}+\gamma_{01} Z_{j}+\mu_{0 j}\right)+\left(\gamma_{10}+\gamma_{11} Z_{j}+\mu_{1 j}\right) x_{i j}+\varepsilon_{i j}$.

Substituting (3) in (4) yields the full model (varying intercept, varying slope model, where both the intercept and the slope vary by country):

$y_{i j}=\gamma_{00}+\gamma_{01} Z_{j}+\beta_{1 j} x_{i j}+\mu_{0 j}+\varepsilon_{i j}$.

The varying slope model (Eq. 3) estimates the effects of macro-indicators on the estimated coefficients of individual-level variables, thus allowing for investigating the pathways linking macro-indicators to the individual capability to volunteer.

\section{Results}

Table 2 displays the results of the first-level estimation for each country. As expected, at the individual level, volunteering is positively associated with different indicators of human, economic, and social capital. Volunteer rates increase with education, positive valuations of health, income, economic status, frequency of contact with friends, and number of children in the household. In many countries, women are less likely to volunteer than men, and age is positively related to volunteering.

The data for the two-level estimation are provided in "Appendix". "Appendix" displays the country mean of volunteering and the coefficients estimated in the first step and selected for the second step of the estimation together with contextual variables. The estimated coefficients of the indicators of individual economic capital (household income), social capital (frequency of contact with friends), and human capital (education), as well as the mean of the dependent variable (formal volunteering), were selected for the second-level estimate. The data for the contextual variables used in the two-level estimation are presented in "Appendix". The two-level estimates include an estimate of $\sigma^{2}$, the variance of the component of the regression residual that is not due to sampling of the dependent variable, and $\omega$, the mean of the variance of that sampling error resulting from the EDV correction (Lewis \& Linzer, 2005).

The results of the second-level estimation are displayed in Tables 3, 4, 5, 6 and 7 (see also "Appendix" for a visualization of the results). First, estimates of the varying-slope model (Eq. 3) in which the slope (i.e. coefficients) varies with a constant intercept are presented in Tables 3, 4, 5 and 6 for the contextual effects of economic, political, social, and 


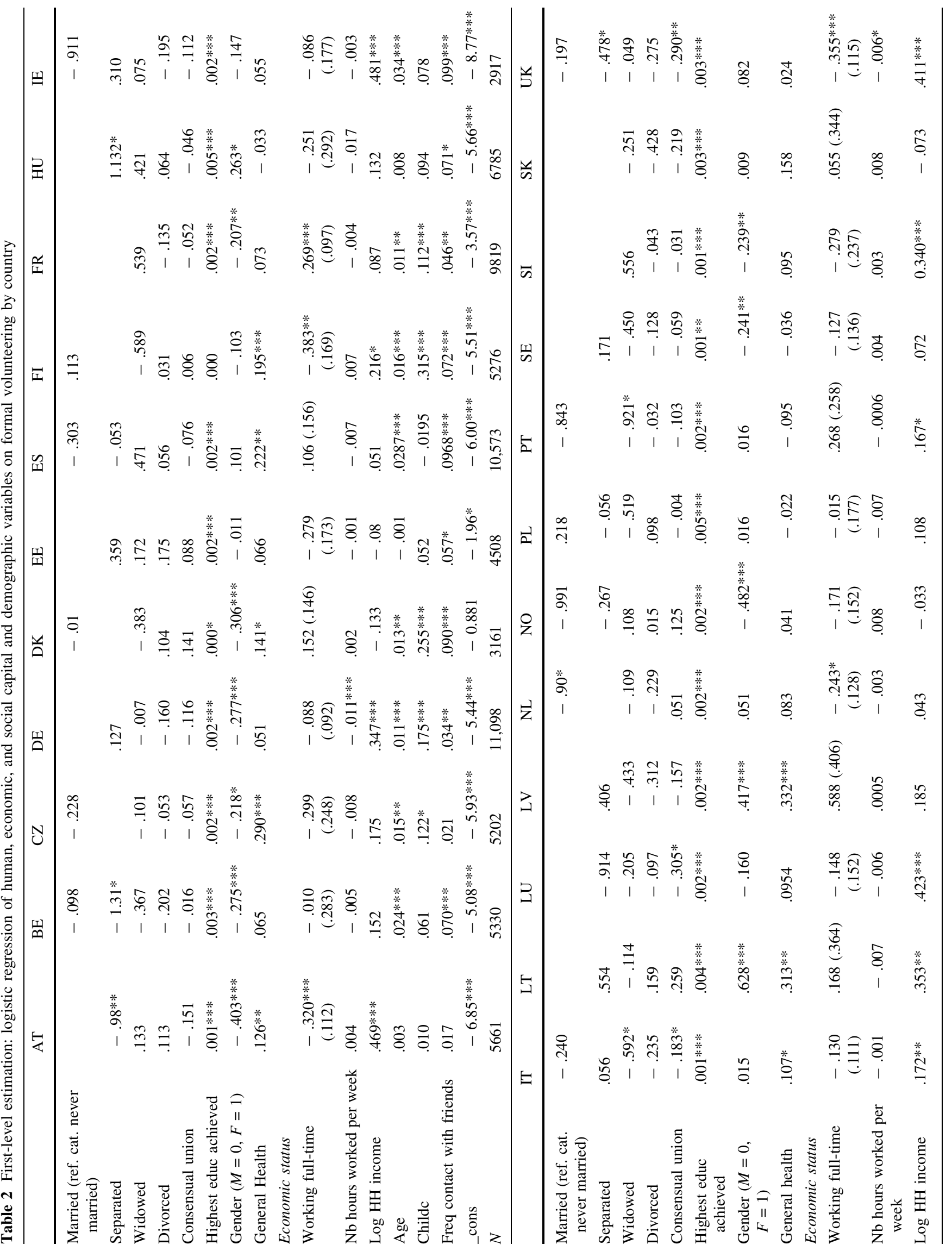




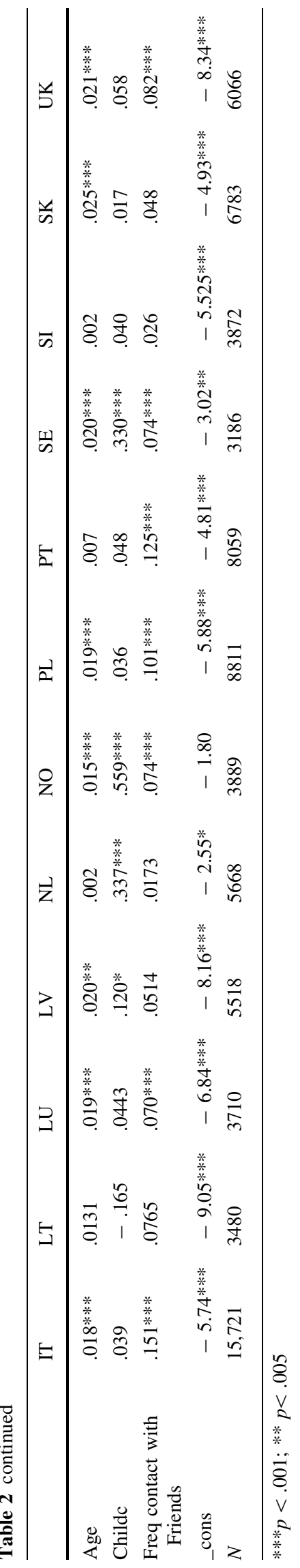

religiosity variables. Next, estimates of the full model, where both the intercept and the slope vary by country (Eq. 5), are presented in Table 7.

The model estimating the contextual effect of the indicators of economic variables on volunteering (Table 3) shows a significant positive effect of the contextual variable GDP per capita and a significant negative effect of the variable Gini index on the mean of volunteering. The variable GDP per capita also has a statistically significant positive effect on the estimated coefficient of individual income and on the estimated coefficient of contact with friends. Similarly, the model estimating the contextual effect of political variables on volunteering (Table 4) shows a statistically significant positive effect of the variable Quality of democracy on the mean of volunteering and a statistically significant negative effect on the estimated coefficient of individual education. In the same vein, the model estimating the contextual effect of the social indicators on volunteering (Table 4) indicates a statistically significant positive effect of the variables Rule of law and Social trust on the mean of volunteering. Finally, the contextual effects of aggregated indicators of religiosity are displayed in Table 6. The results show a statistically negative effect of the importance of religion on the mean of volunteering as well as a statistically significant effect of the importance of religion on the coefficient of social capital.

Overall, the estimation of the varying slope model reveals different pathways and mechanisms linking the main explanatory contextual variables to formal volunteering. As expected, contextual indicators of economic, political, social, and religious factors have a direct impact on volunteer rates. Contextual economic capabilities (GDP per capita) appear to reinforce the effect of individual economic resources (income) on the likelihood of volunteering. Lower levels of inequality and higher levels of social trust might enhance people's shared goals and cooperation and give them the economic resources necessary to devote time to non-paid activities. The mechanisms seem to be different when it comes to the effect of contextual variables through the pathway of contact with friends. In societies characterized by high levels of inequality, having frequent contact with friends appears to increase one's likelihood of volunteering. This type of social capital seems to be more conductive to volunteering in the context of high socioeconomic inequality. Additionally, the indicator of contextual political capabilities measuring civil rights and political liberties negatively impacts the effect of individual education on volunteering, indicating that education plays a more important role as a predictor of volunteering in countries where the scope of civil liberties is narrower. Finally, religiosity does not seem to have a positive impact on volunteering in Europe, in contrast to what appears to be the case in the rest of the world. This may be because Europe is the most secularized 
Table 3 Estimated coefficients as dependent variable in level 2 (Eq. 3)

\begin{tabular}{lllll}
\hline \multicolumn{5}{c}{ Dependent variables: estimates from first step } \\
\cline { 2 - 5 } & $\begin{array}{l}\text { Mean volunteering by } \\
\text { country }\end{array}$ & $\begin{array}{l}\text { Effect of income on } \\
\text { volunteering }\end{array}$ & $\begin{array}{l}\text { Effect of education on } \\
\text { volunteering }\end{array}$ & $\begin{array}{l}\text { Effect of contact with friends on } \\
\text { volunteering }\end{array}$ \\
\hline Gini Index & $-.883^{*}(.482)$ & $1.143(1.064)$ & $.004(.006)$ & $.458^{* *}(.175)$ \\
Log GDP per & $.261^{* * * *(.482)}$ & $.179 *(.095)$ & $-.001(.0007)$ & $.003(.014)$ \\
$\quad$ capita & $-2.268^{* *}(.735)$ & $-2.050^{*}(1.119)$ & $.013(.009)$ & $-.101(.158)$ \\
Cons & .1336 & .0999 & .1696 & .2090 \\
$R$-squared & .081 & .150 & .001 & .022 \\
$\sigma^{2}$ & .003 & .090 & .000 & .021 \\
$\omega$ & 23 & 23 & 23 & 23 \\
$N$
\end{tabular}

Economic contextual variables (GDP, Gini index). Estimated dependent variable with EDV correction (robust standard errors)

$* p>|t|=0.10 ; * *>|t|=0.05 ; * * p>|t|=0.01$

region of the world. However, religiosity at the macro-level has a positive effect on volunteering through the pathway of social networks.

The estimation of the full model (Eq. 5) presented in Table 5 confirms the insights provided by the varying slope estimation results. Individual social and human capital are positively associated with volunteering. High levels of personal income are negatively associated with volunteering as the cost of free time increases. At the contextual level, economic prosperity (as measured by GDP per capita), indicators of social trust, civil rights, and political liberties are positively associated with volunteering. Conversely, high levels of inequality, high levels of religious fragmentation, and religiosity are negatively associated with volunteering.

\section{Discussion}

The results of both the varying slope model and the full model support hypotheses 1 to 4 but partially do not support hypothesis 5 . The first hypothesis, suggesting that individual forms of (economic, human, and social) capital are positively associated with volunteering, constituting resources that individuals can transform into functioning (volunteering), is clearly supported by the results. However, if, in many individual European countries, individuals with higher incomes (economic capital) have a higher likelihood of volunteering, the relationship between income and volunteering is negative for the 23 countries considered together and when controlling for GDP per capita and level of inequality (as shown in Table 7), revealing the influence of macro-structural economic factors on the relationship between individual income and volunteering. In rich countries, the substitution effect between income and free time appears to be negative, whereas it is positive in less affluent countries. As expected, according to hypothesis 2, countries' economic prosperity enhances volunteering, whereas high levels of inequality reduce individuals' volunteering capability. Hypothesis 3 , positing that a positive relationship exists between political pluralism and civil liberties on the one hand and the capability to volunteer on the other hand, is also supported by the findings. The same applies to hypothesis 4 , which proposes the existence of a positive relationship between indicators of social trust and the capability to volunteer. The last hypothesis, however, is not fully supported. There appears to exist a negative relationship between a country's degree of religiosity and the capability to volunteer, despite the presence of religiosity enhancing social networks that, in turn, positively influence the capability to volunteer. Overall, the results are in line with the findings of Damian (2018) concerning the contextual effect of cultural (religiosity) and economic (GDP; inequality) characteristics. They also provide evidence of the effects of social trust and civil liberties.

In sum, the second step of the analysis revealed a complex relationship between economic factors (especially economic inequality measured through the Gini index) and social capital (social trust and contact with friends) at the contextual level. National wealth measured by GDP by capita is positively associated with volunteering. However, more than the level of economic resources, the way these economic resources are distributed appears to play a central role in explaining differences in volunteering. Increased inequality significantly reduces the likelihood of volunteering. There is clearly a direct pathway from equal distribution of economic resources to volunteering. The results from the second step allow us to identify an indirect pathway linking equality with volunteering through the mediation of social trust. Social trust increases the likelihood of volunteering (direct effect) because it enhances cooperation, thus facilitating the achievement of common goals through voluntary action. Social capital measured through the frequency of contact with 
Table 4 Estimated coefficients as dependent variable in level 2 (Eq. 3)

\begin{tabular}{|c|c|c|c|c|}
\hline & \multicolumn{4}{|c|}{ Dependent variables: estimates from first step } \\
\hline & $\begin{array}{l}\text { Mean volunteering by } \\
\text { country }\end{array}$ & $\begin{array}{l}\text { Effect of income on } \\
\text { volunteering }\end{array}$ & $\begin{array}{l}\text { Effect of education on } \\
\text { volunteering }\end{array}$ & $\begin{array}{l}\text { Effect of contact with friends on } \\
\text { volunteering }\end{array}$ \\
\hline Political pluralism & $.047(.030)$ & $.021(.046)$ & $.0005(.0003)$ & $.002(.019)$ \\
\hline $\begin{array}{l}\text { Civil rights and political } \\
\text { liberties }\end{array}$ & $.074 * * * *(.018)$ & $-.022(.039)$ & $-.0006^{* * *}(.0002)$ & $.0009(.004)$ \\
\hline Cons & $-1.095 * *(.423)$ & $.033(.701)$ & $-.0004(.004)$ & $.015(.291)$ \\
\hline$R$-squared & .5150 & .0137 & .2980 & .0049 \\
\hline$\sigma^{2}$ & .094 & .165 & .0009 & .027 \\
\hline$\omega$ & .003 & .090 & .0003 & .021 \\
\hline$N$ & 23 & 23 & 23 & 23 \\
\hline
\end{tabular}

Political contextual variables (political pluralism, quality of democracy). Estimated dependent variable with EDV correction (robust standard errors)

$* p>|t|=0.10 ; * *>|t|=0.05 ; * * p>|t|=0.01$

Table 5 Estimated coefficients as dependent variable in level 2 (Eq. 3)

\begin{tabular}{lllll}
\hline \multicolumn{5}{c}{ Dependent variables: estimates from first step } \\
\cline { 2 - 5 } & $\begin{array}{l}\text { Mean volunteering by } \\
\text { country }\end{array}$ & $\begin{array}{l}\text { Effect of income on } \\
\text { volunteering }\end{array}$ & $\begin{array}{l}\text { Effect of education on } \\
\text { volunteering }\end{array}$ & $\begin{array}{l}\text { Effect of contact with friends on } \\
\text { volunteering }\end{array}$ \\
\hline $\begin{array}{l}\text { Rule of } \\
\text { law }\end{array}$ & $.027 * *(.011)$ & $.049(.029)$ & $-.0002(.00019)$ & $.0007(.006)$ \\
$\begin{array}{c}\text { Social } \\
\text { trust }\end{array}$ & $.008^{* * *}(.002)$ & $-.009(.005)$ & $-.00003(.00002)$ & $-.0007(.001)$ \\
Cons & $-.560^{* * *}(.097)$ & $-.042(.265)$ & $.007 * *(.002)$ & $.091(.069)$ \\
$R$-squared & .7206 & .1351 & .3371 & .0265 \\
$\sigma^{2}$ & .071 & .151 & .0009 & .027 \\
$\omega$ & .003 & .090 & .0003 & .021 \\
$N$ & 23 & 23 & 23 & 23
\end{tabular}

Social contextual variables (social trust, rule of law). Estimated dependent variable with EDV correction (robust standard errors)

$* p>|t|=0.10 ; * * p|t|=0.05 ; * * * p>|t|=0.01$

Table 6 Estimated coefficients as dependent variable in level 2 (Eq. 3)

\begin{tabular}{|c|c|c|c|c|}
\hline & \multicolumn{4}{|c|}{ Dependent variables: estimates from first step } \\
\hline & $\begin{array}{l}\text { Mean volunteering by } \\
\text { country }\end{array}$ & $\begin{array}{l}\text { Effect of income on } \\
\text { volunteering }\end{array}$ & $\begin{array}{l}\text { Effect of education on } \\
\text { volunteering }\end{array}$ & $\begin{array}{l}\text { Effect of contact with friends on } \\
\text { volunteering }\end{array}$ \\
\hline $\begin{array}{l}\text { Religion } \\
\text { fractionalization }\end{array}$ & $.044(.031)$ & $-.011(.050)$ & $.0006(.002)$ & $.003(.018)$ \\
\hline $\begin{array}{l}\text { Freedom expression } \\
\text { and belief }\end{array}$ & $.071 * * *(.020)$ & $-.033(.043)$ & $-.0007 * * *(.0002)$ & $-.0005(.005)$ \\
\hline Importance religion & $-.290 * *(.121)$ & $.246(.265)$ & $.003(.002)$ & $.118 * *(.050)$ \\
\hline Cons & $-.891(.475)$ & $.484(.941)$ & $-.002(.005)$ & $-.061(.171)$ \\
\hline$R$-squared & .5855 & .0883 & .4801 & .2098 \\
\hline$\sigma^{2}$ & .083 & .131 & .001 & .017 \\
\hline$\omega$ & .003 & .090 & .0003 & .021 \\
\hline$N$ & 23 & 23 & 23 & 23 \\
\hline
\end{tabular}

Religious contextual variables (social trust, rule of law). Estimated dependent variable with EDV correction (robust standard errors)

$* p>|t|=0.10 ; * * p>|t|=0.05 ; * * * p>|t|=0.01$ 
Table 7 Second level estimation: full model (Eq. 5)

\begin{tabular}{|c|c|c|c|c|}
\hline & $\begin{array}{l}\text { Model } 1 \\
\text { Economic contextual } \\
\text { variables }\end{array}$ & $\begin{array}{l}\text { Model } 2 \\
\text { Social contextual } \\
\text { variables }\end{array}$ & $\begin{array}{l}\text { Model } 3 \\
\text { Political contextual } \\
\text { variables }\end{array}$ & $\begin{array}{l}\text { Model } 4 \\
\text { Religiosity contextual } \\
\text { variables }\end{array}$ \\
\hline Social capital & $.168(.229)$ & $.081 * * *(.024)$ & $.024 * * *(.025)$ & $.115^{* * *}(.024)$ \\
\hline Education & $-16.880(9.625)$ & $.073 * * *(.014)$ & $.164 * * *(.015)$ & $.109 * * *(.015)$ \\
\hline Income & $-.164 * * *(.038)$ & $-.006 *(.002)$ & $-.011 * * *(.003)$ & $.0039(.003)$ \\
\hline Gini index & $-.916 * * *(.024)$ & - & - & - \\
\hline Log GDP per capita & $.265 * * *(.233)$ & - & - & - \\
\hline Political pluralism & - & - & $(.019)(.015)$ & - \\
\hline $\begin{array}{l}\text { Civil rights and political } \\
\text { liberties }\end{array}$ & - & - & $.118 * * *(.006)$ & - \\
\hline Rule of law & - & $.018 * *(.005)$ & - & - \\
\hline Social trust & - & $.009 * * *(.0006)$ & - & - \\
\hline Religion fractionalization & - & - & - & $-.741 * * *(.052)$ \\
\hline $\begin{array}{l}\text { Freedom expression and } \\
\text { belief }\end{array}$ & - & - & - & $-.031 * * *(.007)$ \\
\hline Importance Religion & & - & - & $-.840 * * *(.045)$ \\
\hline Cons & $-2.271 * * *(.295)$ & $-.612 * * *(.083)$ & $-1.174 * * *(.236)$ & $1.218 * * *(.145)$ \\
\hline R-squared & .2396 & .244 & .245 & .249 \\
\hline$\sigma^{2}($ EDV Correction $)$ & -.0083 & -.0092 & -.0094 & -.0103 \\
\hline$\omega$ (Residual standard error) & .9736 & .9707 & .9698 & .967 \\
\hline $\mathrm{N}$ & 23 & 23 & 23 & 23 \\
\hline
\end{tabular}

Estimated dependent variable with EDV correction (robust standard errors)

$* p>|t|=0.10 ; * * p|t|=0.05 ; * * p>|t|=0.01$

friends appears to be more important in predicting volunteering in countries with higher levels of economic inequality. In addition, if, as Uslaner and Brown's (2005) asserted, that inequality contributes to a decline in social trust, we identified the contours of a complex pathway connecting inequality, social trust, and volunteering, where equality and social trust reinforce each other and enhance volunteering.

As shown in Fig. 2, European countries form four clusters when volunteer rates are plotted against levels of inequality and social trust. This relationship between volunteering and inequality and trust allows for linking these findings based on the capability approach to the social origins of civil society and the welfare regime approaches that attribute differences in volunteering rates to different institutional arrangements characterizing civil societies and welfare states across Europe. These approaches emphasize the relative division of tasks and responsibilities between the welfare state, the market, and family. Different welfare regimes, such as the Nordic, Continental, Anglo-Saxon, post-Communist, and Mediterranean regimes, appear to be associated with different levels and types of volunteering (Gil-Lacruz \& Marcuello-Servos, 2013; Salamon et al., 2017).

A way to classify these regimes is to assess the correlation between government social welfare spending and formal volunteering (Salamon \& Sokolowski, 2003). The Nordic and Anglo-Saxon countries are characterized by high levels of social welfare spending and high rates of volunteering. Continental countries combine higher levels of social welfare spending with medium levels of volunteering, whereas Mediterranean countries display lower levels of social welfare spending and lower levels of volunteering than the Continental countries. Finally, post-Communist countries appear to be characterized by low levels of social welfare spending and low levels of volunteering.

Another way to classify these regimes is to examine, as shown in Fig. 2, correlations between formal volunteering, inequality, and social trust. From this viewpoint, the Nordic countries have low levels of inequality, high levels of social trust, and high rates of volunteering. The Continental countries have medium levels of inequality, social trust, and volunteering. The Mediterranean countries have high levels of inequality, relatively low levels of social trust, and medium-low volunteer levels. The post-Communist countries have low levels of inequality but also low levels of volunteering and social trust. The Anglo-Saxon type, represented by the UK, is somewhat an exception with high levels of inequality and medium-high levels of social trust and volunteering. These correlations show a relationship between institutional features (welfare regimes, civil society regimes) and capabilities identified in terms of inequality and social trust. The institutional regimes (e.g. the Nordic and Continental welfare and civil society 


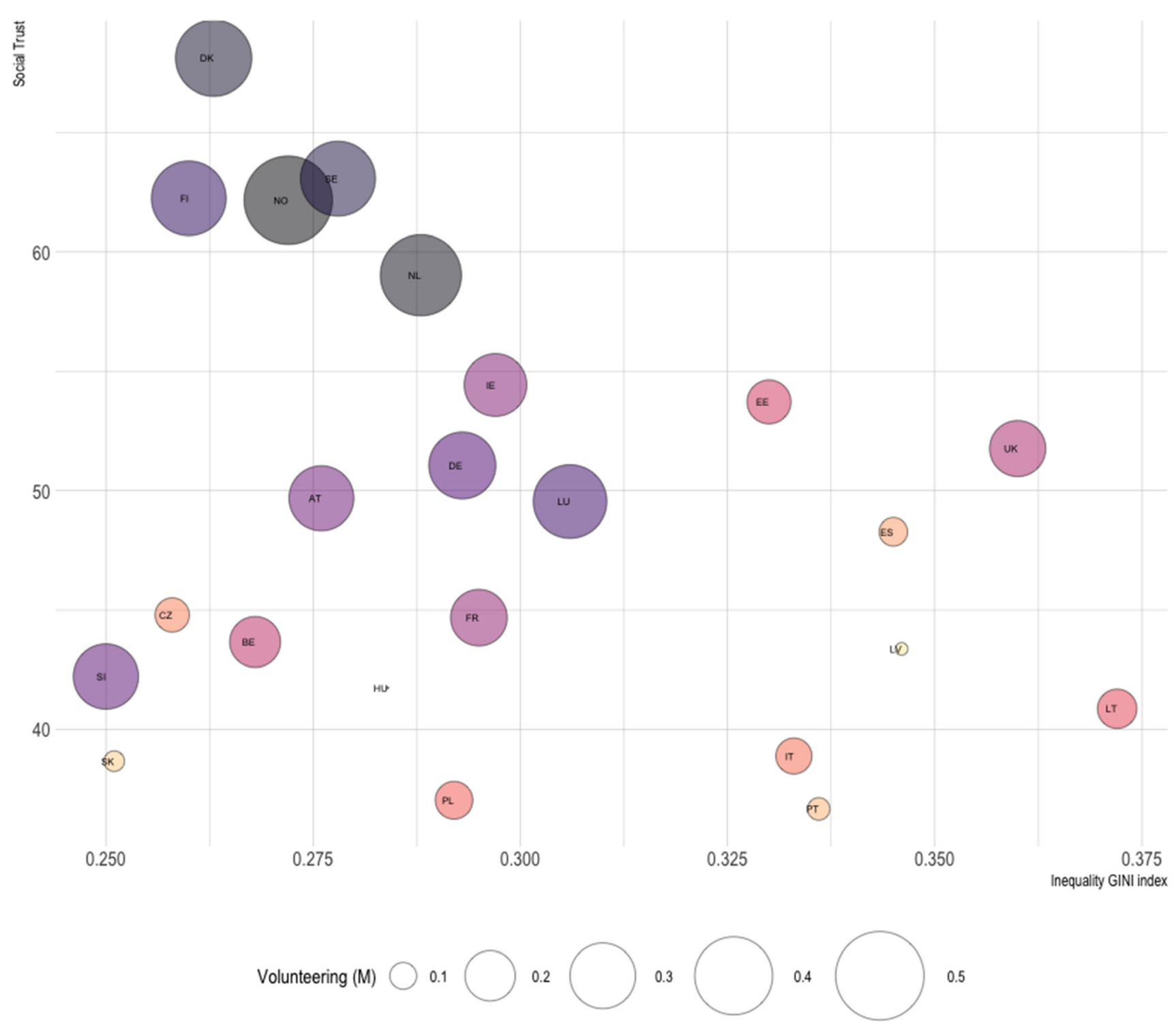

Fig. 2 Formal volunteering in relation to inequality and social trust ( Source: author based on EU-SICL-2015 data)

regimes) that redistribute the most and, therefore, are able to reduce inequality, are those that have higher levels of social trust and formal volunteering. In the Mediterranean welfare and civil society regime, inequality and social trust reinforce each other and entail low levels of volunteering. In most post-Communist countries, inequality rates are relatively low, but social trust is lacking as a result of decades of dictatorship, explaining the low volunteer rates.

\section{Conclusions}

The objective of this study was to propose and test a theoretical understanding of cross-country differences in formal volunteering in Europe based on the capability approach. For this purpose, the capability approach emphasizing the democratic and socioeconomic factors that enable individuals to choose volunteer activities was operationalized using indicators of individual and contextual economic, political, social, and religious determinants. The results of the empirical analysis based on the 2015 EU-SILC data support the capability hypothesis at the individual and contextual levels. At the individual level, indicators of human capital (education and health), economic capital (household income, occupational status), and social capital (frequency of contact with friends, number of children living in the household) have a positive effect on the likelihood of volunteering. At the contextual level, the macro-structural social equality indicator (the Gini index) is negatively associated with volunteer rates. That is, a more equal distribution of resources increases individual capabilities to volunteer. Additionally, macro-structural indicators of 
democracy (civil liberties) and horizontal social capital (social trust) are positively associated with volunteer rates. European countries cluster in different civil society regimes according to their levels of inequality and social trust - that is, along two important capability dimensions. Thus, on the basis of this analysis, it is possible to conclude that equality and social trust might be considered the main pathways through which historically inherited institutional features enhance individual capabilities to volunteer and, consequently, account for differences in volunteer rates across European countries. The differential abilities of these institutional regimes to sustain low levels of economic inequality and high levels of social trust over time might be thought of as enhancing individual and collective capabilities and, in turn, to be the key determinants of the vitalism of civil society expressed in terms of levels of formal volunteering.
Eurostat. Because of Eurostat's regulation, it is not possible to make the micro-data in a data repository.

\section{Declarations}

Conflict of interest The author declares that he has no conflict of interest.

Open Access This article is licensed under a Creative Commons Attribution 4.0 International License, which permits use, sharing, adaptation, distribution and reproduction in any medium or format, as long as you give appropriate credit to the original author(s) and the source, provide a link to the Creative Commons licence, and indicate if changes were made. The images or other third party material in this article are included in the article's Creative Commons licence, unless indicated otherwise in a credit line to the material. If material is not included in the article's Creative Commons licence and your intended use is not permitted by statutory regulation or exceeds the permitted use, you will need to obtain permission directly from the copyright holder. To view a copy of this licence, visit http://creativecommons.org/licenses/by/4.0/.

Funding The study was carried with no particular funding.

Data availability The macro-level data for the analysis are made available in "Appendix". The micro-level data are provided by

\section{Appendix}

See Tables 8, 9 and Figs. 3, 4, 5, 6, 7, 8, 9, 10.

Table 8 Estimated mean of volunteering and significant first-level regression coefficients by country in the two-level analysis

\begin{tabular}{|c|c|c|c|c|c|}
\hline Country & $\begin{array}{l}\text { Mean (standard } \\
\text { error) }\end{array}$ & $\begin{array}{l}\text { Estimated coefficient log } \\
\text { (income) }^{\dagger}\end{array}$ & $\begin{array}{l}\text { Estimated coefficient frequency contact } \\
\text { with friends }{ }^{\dagger}\end{array}$ & $\begin{array}{l}\text { Estimated coefficient of } \\
\text { education }\end{array}$ & $N$ \\
\hline AT & $.296(.004)$ & $.469 * * *(.060)$ & $.017(.014)$ & $.001 * * *(.0002)$ & 5561 \\
\hline $\mathrm{BE}$ & $.204(.003)$ & $.151 * *(.086)$ & $.07 * * *(.017)$ & $.003^{* * *}(.0004)$ & 5330 \\
\hline $\mathrm{CZ}$ & $.125(.002)$ & $.327 * *(.054)$ & $.021(.023)$ & $.002 * * *(.0006)$ & 5202 \\
\hline $\mathrm{DE}$ & $.312(.003)$ & $.346 * * *(.049)$ & $.034 * *(.011)$ & $.002 * * *(.0002)$ & 11,098 \\
\hline DK & $.387(.006)$ & $-.132(.132)$ & $.09^{* * *}(.023)$ & $.002 * * *(.0004)$ & 3161 \\
\hline $\mathrm{EE}$ & $.167(.003)$ & $-.08(.071)$ & $.057 * *(.023)$ & $.000 *(.0004)$ & 4508 \\
\hline ES & $.105(.001)$ & $.05(.071)$ & $.096 * * *(.019)$ & $.002 * * *(.0003)$ & 10,573 \\
\hline FI & $.374(.004)$ & $.215^{* *}(.089)$ & $.072 * * *(.018)$ & $.002 * * *(.0003)$ & 5276 \\
\hline FR & $.239(.002)$ & $.087(.065)$ & $.046 * *(.016)$ & $.000(.0003)$ & 9819 \\
\hline $\mathrm{HU}$ & $.063(.001)$ & $.131(.129)$ & $.071 * *(.033)$ & $.002 * * *(.0006)$ & 6785 \\
\hline IE & $.279(.005)$ & $.480 * * *(.112)$ & $.099 * * *(.026)$ & $.005^{* * *}(.0004)$ & 2917 \\
\hline IT & $.132(.001)$ & $.171 * *(.063)$ & $.151 * * *(.014)$ & $.002 * * *(.0002)$ & 15,721 \\
\hline $\mathrm{LT}$ & $.146(.003)$ & $.353 * *(.123)$ & $.076 * *(.040)$ & $.002 * * *(.0008)$ & 3480 \\
\hline LU & $.364(.005)$ & $.423 * * *(.097)$ & $.070 * * *(.020)$ & $.001 * * *(.0003)$ & 3710 \\
\hline LV & $.070(.002)$ & $.185^{* *}(.102)$ & $.051 * *(.031)$ & $.004 * * *(.0005)$ & 5518 \\
\hline NL & $.431(.005)$ & $.043(.106)$ & $.017(.020)$ & $.002 * * *(.0003)$ & 5668 \\
\hline NO & $.501(.006)$ & $-.033(.097)$ & $.074 * * *(.018)$ & $.002 * * *(.0003)$ & 3889 \\
\hline PL & $.138(.002)$ & $.107(.065)$ & $.100 * * *(.021)$ & $.002 * * *(.0005)$ & 8811 \\
\hline PT & $.088(.002)$ & $.166 * *(.077)$ & $.125^{* * *}(025)$ & $.002 * * *(.0003)$ & 8059 \\
\hline SE & $.376(.006)$ & $.072(.094)$ & $.074 * * *(.021)$ & $.005^{* * *}(.0004)$ & 3186 \\
\hline SI & $.298(.004)$ & $.34 * * *(.087)$ & $.026(.021)$ & $.002 * * *(.0004)$ & 3872 \\
\hline SK & $.084(.002)$ & $-.073(.116)$ & $.048(.030)$ & $.001 * *(.0006)$ & 6783 \\
\hline UK & $.236(.003)$ & $.411 * * *(.072)$ & $.082 * * *(.017)$ & $.001 * * *(.0003)$ & 6066 \\
\hline Total & $.208(.007)$ & - & - & - & 139,791 \\
\hline
\end{tabular}

${ }^{\dagger}$ The variables in the first-step estimation of volunteering are marital status, education, gender, health, economic status, weekly hours worked, household disposable income, age, number of children, and frequency of contact with friends 
Table 9 Contextual variables in the two-level analysis $(N=23)$

\begin{tabular}{|c|c|c|c|c|c|c|}
\hline Country & Log GDP capita & Gini index & Political pluralism & Civil rights and liberties & Rule of law & Social trust \\
\hline AT & 10.81828 & .276 & 15 & 7.3333335 & 15 & 49.68192 \\
\hline $\mathrm{BE}$ & 10.72856 & .268 & 16 & 7.3333335 & 14 & 43.66128 \\
\hline $\mathrm{CZ}$ & 10.41866 & .258 & 15 & 7 & 14 & 44.79235 \\
\hline $\mathrm{DE}$ & 10.77671 & .293 & 15 & 8.666667 & 14 & 51.05424 \\
\hline DK & 10.79773 & .263 & 16 & 8.666667 & 15 & 68.1172 \\
\hline $\mathrm{EE}$ & 10.28072 & .33 & 15 & 8.666667 & 14 & 53.71986 \\
\hline ES & 10.45972 & .345 & 16 & 7.3333335 & 15 & 48.27694 \\
\hline FI & 10.64694 & .26 & 16 & 9.333333 & 16 & 62.24467 \\
\hline FR & 10.61065 & .295 & 15 & 7.6666665 & 13 & 44.67839 \\
\hline $\mathrm{HU}$ & 10.1731 & .284 & 15 & 5 & 10 & 41.74631 \\
\hline IE & 11.13866 & .297 & 16 & 9 & 14 & 54.42649 \\
\hline IT & 10.50857 & .333 & 14 & 7.3333335 & 12 & 38.88335 \\
\hline $\mathrm{LT}$ & 10.26775 & .372 & 16 & 8 & 13 & 40.86678 \\
\hline LU & 11.52805 & .306 & 16 & 8.333333 & 16 & 49.54649 \\
\hline LV & 10.10695 & .346 & 14 & 8 & 12 & 43.3674 \\
\hline NL & 10.82035 & .288 & 16 & 8.666667 & 15 & 59.02126 \\
\hline $\mathrm{NO}$ & 11.03025 & .272 & 16 & 9.333333 & 16 & 62.16695 \\
\hline PL & 10.17667 & .292 & 16 & 8.333333 & 13 & 37.03305 \\
\hline PT & 10.29324 & .336 & 16 & 8 & 15 & 36.66931 \\
\hline SE & 10.77709 & .278 & 16 & 9.333333 & 16 & 63.06744 \\
\hline SI & 10.35685 & .25 & 16 & 7.6666665 & 14 & 42.21521 \\
\hline SK & 10.29622 & .251 & 15 & 6.6666665 & 12 & 38.66837 \\
\hline UK & 10.63941 & .36 & 16 & 7.3333335 & 15 & 51.76307 \\
\hline
\end{tabular}

Fig. 3 Relationship between economic structural factors and average percentage of population active as formal volunteer ( Source: author based on EU-SICL-2015 data)
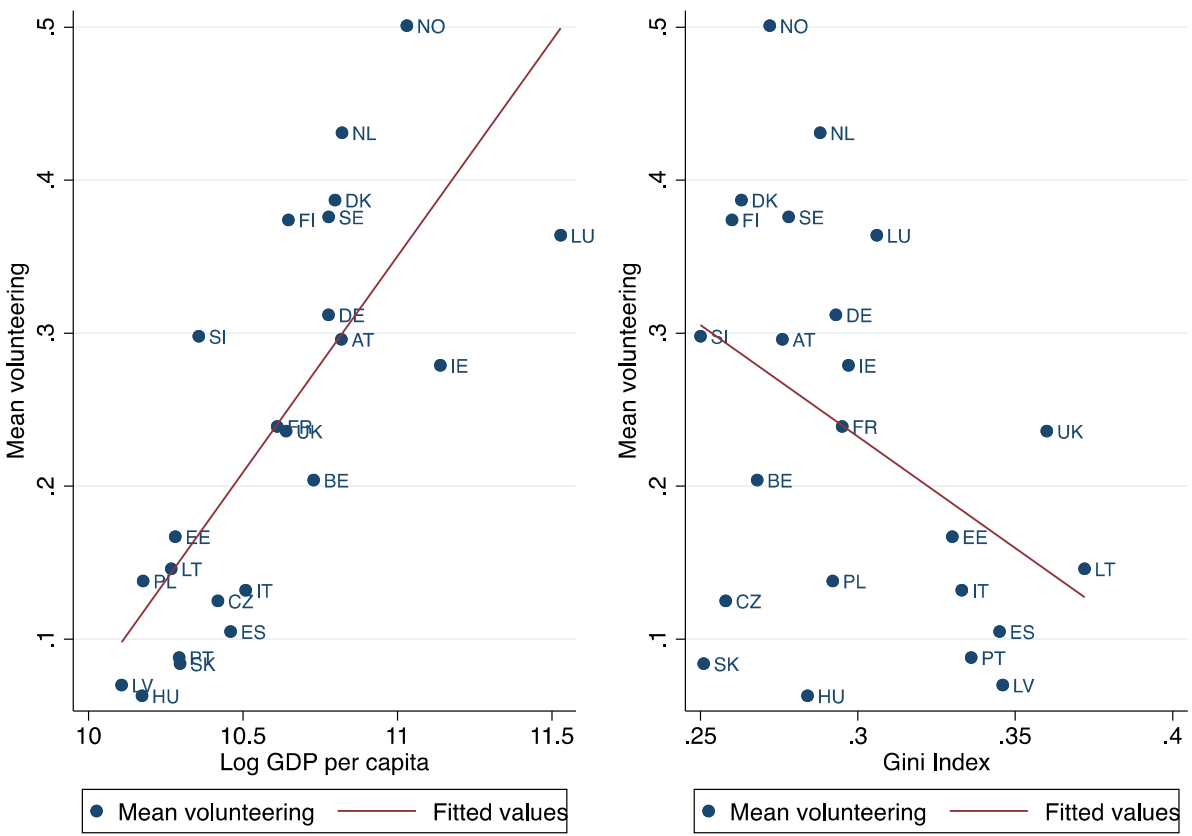
Fig. 4 Relationship between political structural factors and average percentage of population active as formal volunteer ( Source: author based on EU-SICL-2015 data)

Fig. 5 Relationship between social structural factors and average percentage of population active as formal volunteer ( Source: author based on EU-SICL-2015 data)
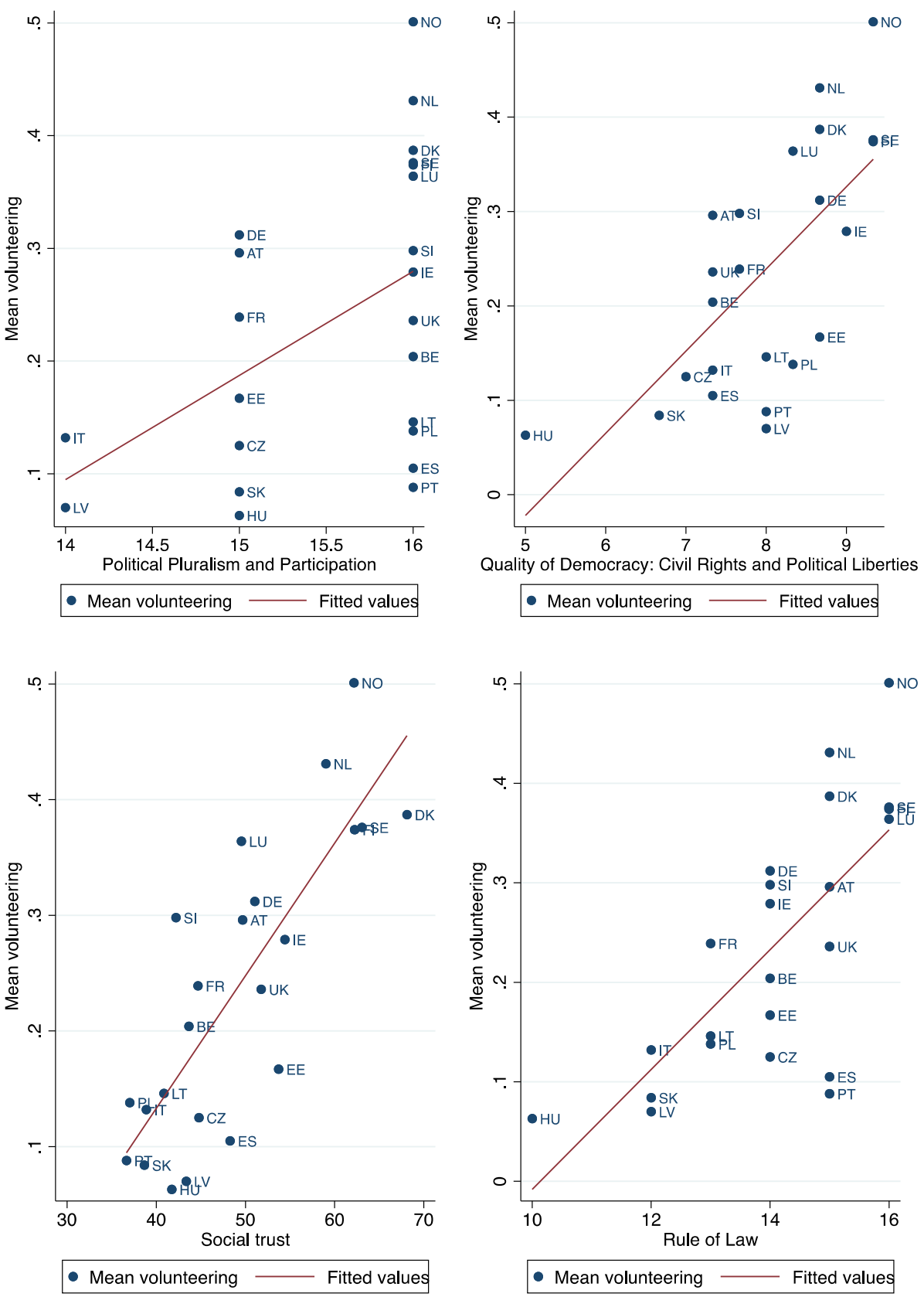
Fig. 6 Relationship between religious structural factors and average percentage of population active as formal volunteer ( Source: author based on EU-SICL-2015 data)

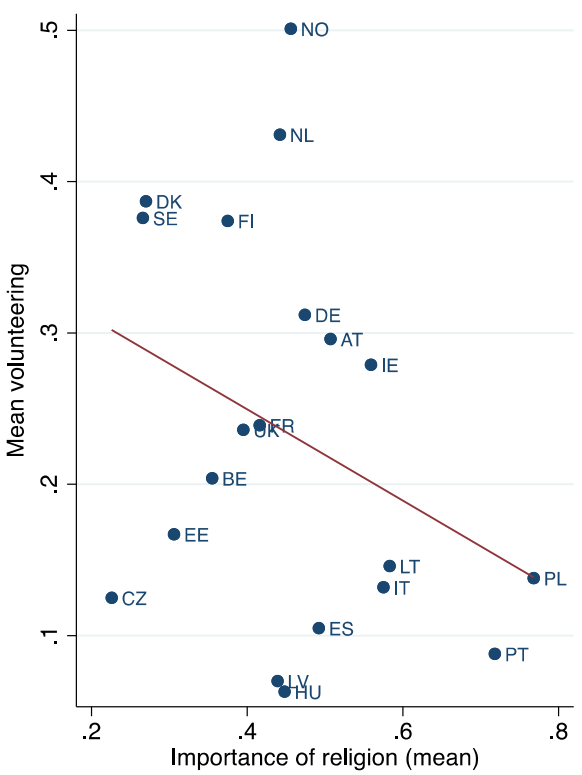

- Mean volunteering $\longrightarrow$ Fitted values

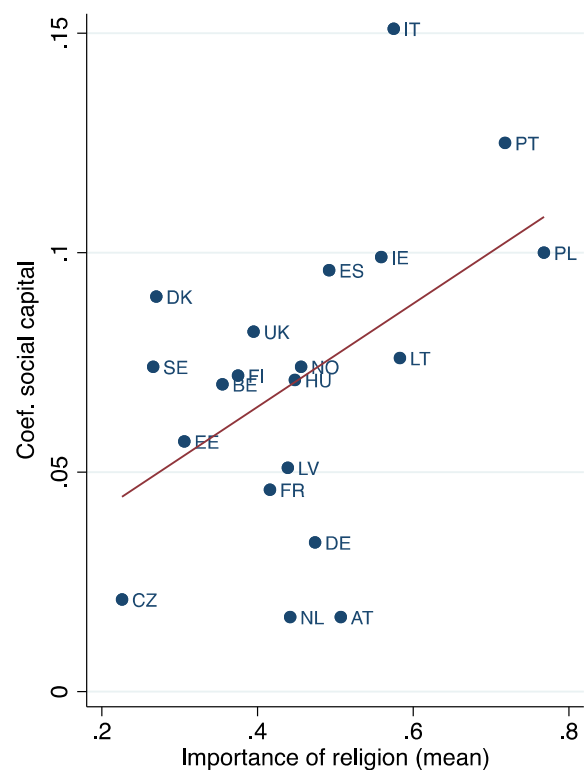

- coef. social capital — Fitted values
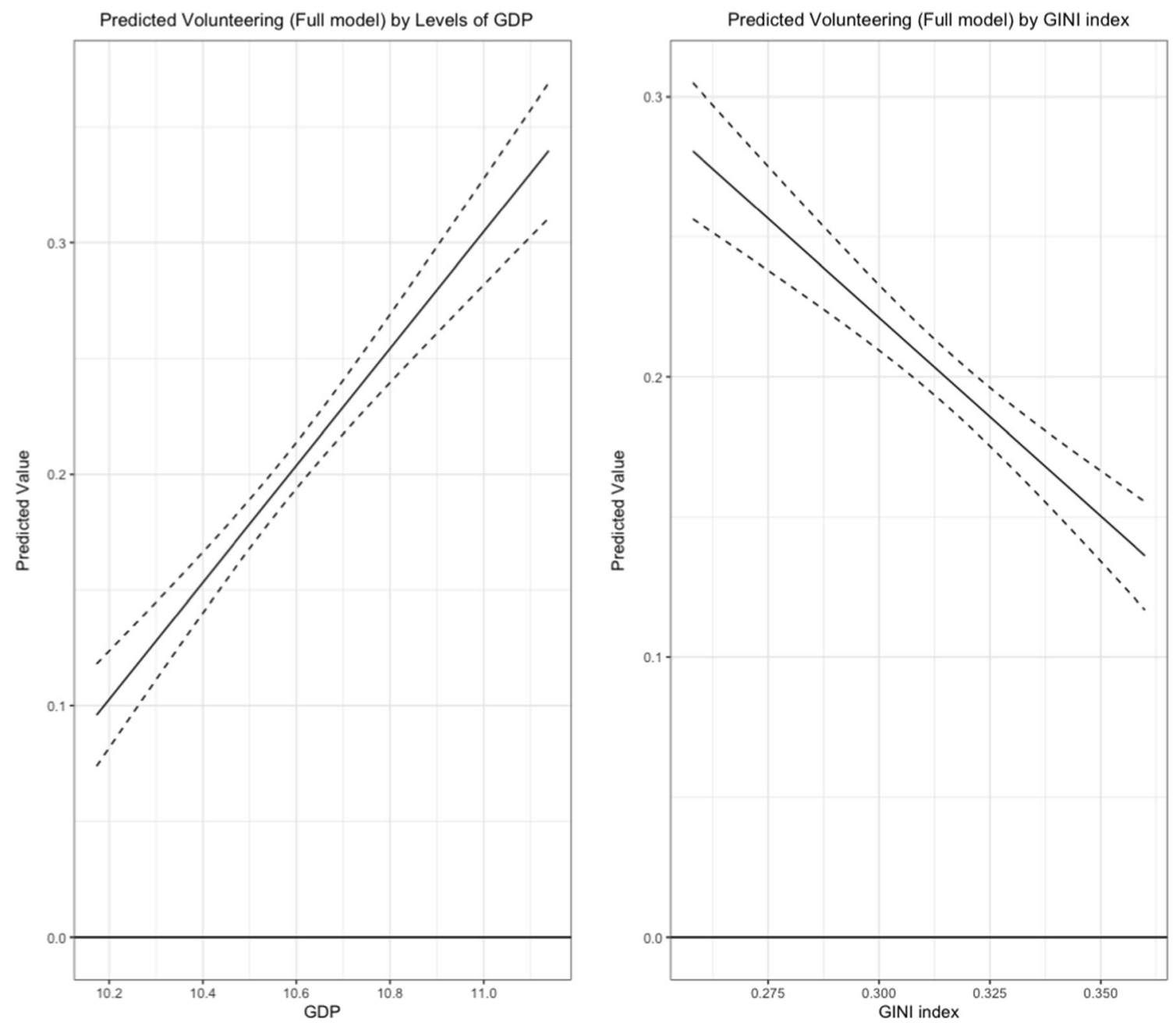

Fig. 7 Marginal effects of macro-economic structural factors on individual volunteering (Full Model-Eq. 5) 

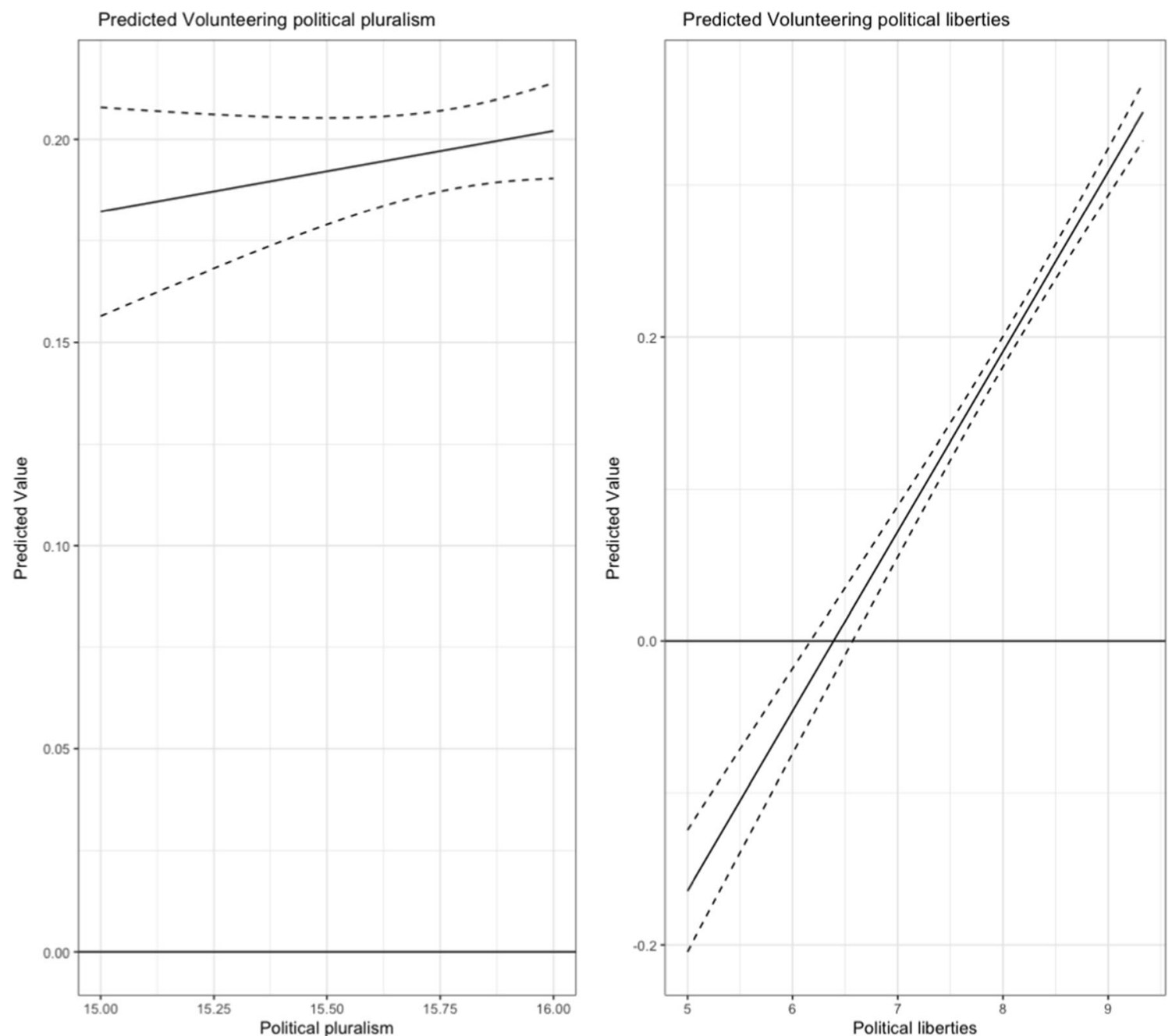

Fig. 8 Marginal effects of macro-political structural factors on individual volunteering (Full Model-Eq. 5) 

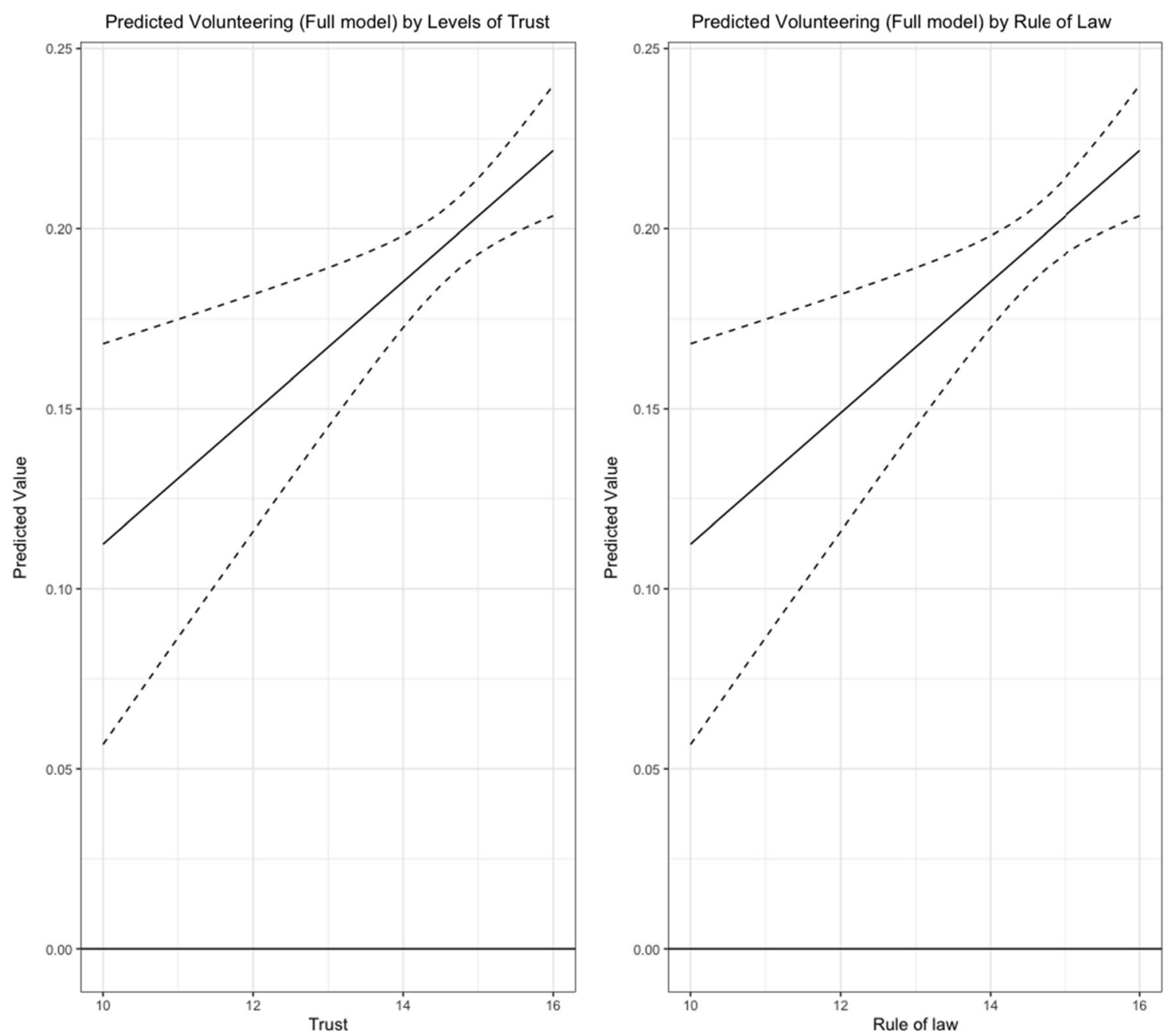

Fig. 9 Marginal effects of macro-social structural factors on individual volunteering (Full Model-Eq. 5) 

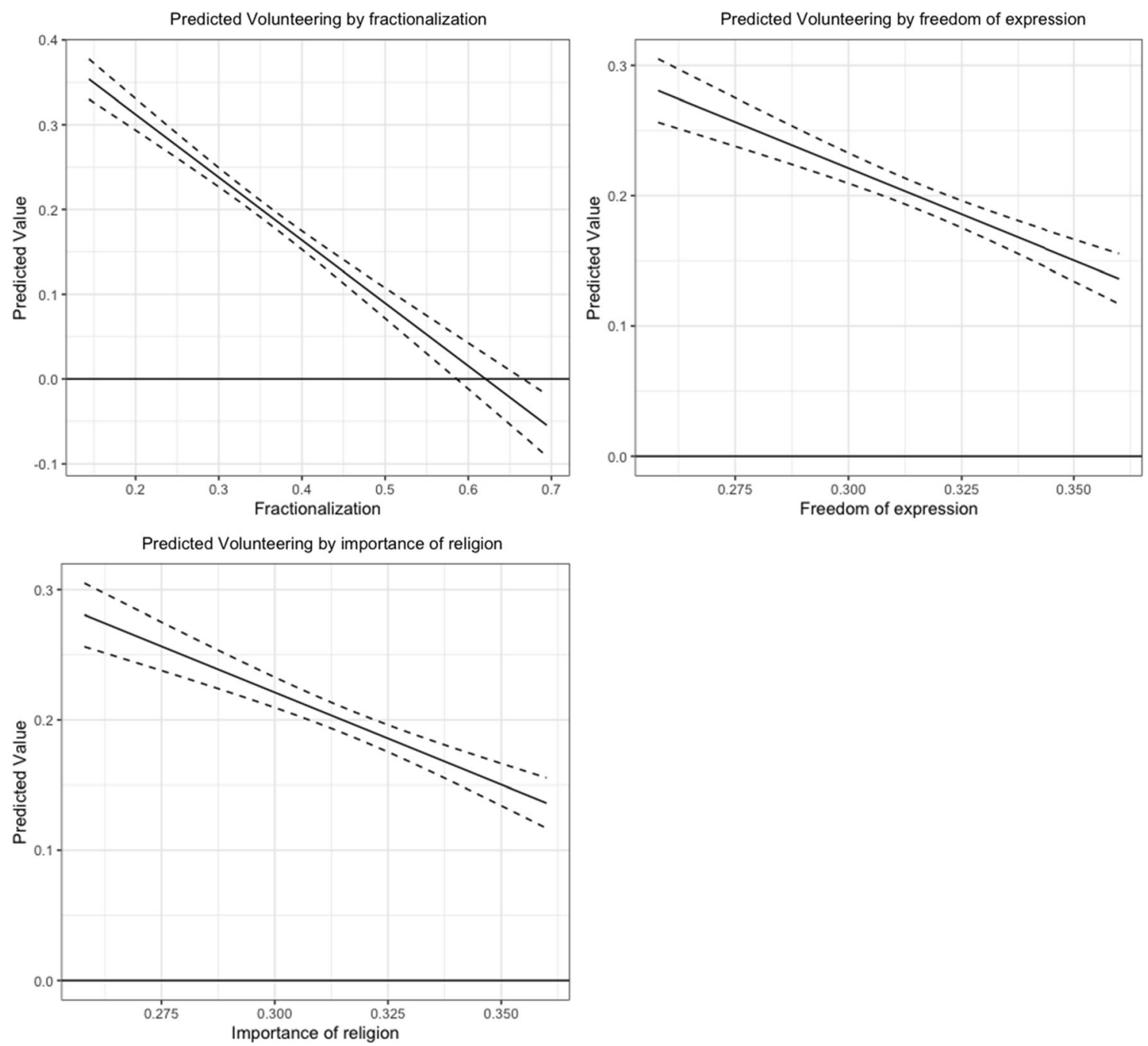

Fig. 10 Marginal effects of macro-religious structural factors on individual volunteering (Full Model-Eq. 5)

\section{References}

Alesina, A., Devleeschauwer, A., Easterly, W., Kurlat, S., \& Wacziarg, R. (2003). Fractionalization. Journal of Economic Growth, 8(2), 155-194.

Alesina, A., \& La Ferrara, E. (2000). Participation in heterogeneous communities. The Quarterly Journal of Economics, 115(3), 847-904.

Anderson, L. R., Mellor, J. M., \& Milyo, J. (2008). Inequality and public good provision: An experimental analysis. The Journal of Socio-Economics, 37(3), 1010-1028.

Anheier, H. K., Lang, M., \& Toepler, S. (2020). Comparative nonprofit sector research: A critical assessment. In W. W. Powell \& P. Bromley (Eds.), The nonprofit sector: A research handbook. (3rd ed., pp. 719-743). Stanford University Press.

Baer, D., Prouteau, L., Swindell, D., Savicka, A., Smith, D. H., \& Tai, K. T. (2016). Conductive macro-contexts influencing volunteering. In D. H. Smith, R. A. Stebbins, \& J. Grotz (Eds.), The Palgrave handbook of volunteering, civic participation, and nonprofit associations. (pp. 580-606). Palgrave Macmillan.

Becker, G. S. (1993). Human capital: A theoretical and empirical analysis, with special reference to education. University of Chicago Press. (Original work published 1963)
Bennett, M. R. (2015). Religiosity and formal volunteering in global perspective. In L. Hustinx, J. von Essen, J. Haers, \& S. Mels (Eds.), Religion and volunteering. Complex, contested and ambiguous relationships. (pp. 77-120). Springer.

Bjørnskov, C. (2006). Determinants of generalized trust: A crosscountry comparison. Public Choice, 130, 1-21.

Borgonovi, F. (2008). Divided we stand, united we fall: Religious pluralism, giving, and volunteering. American Sociological Review, 73(1), 105-128.

Borjas, G. J., \& Sueyoshi, G. T. (1994). A two-stage estimator for probit models with structural group effects. Journal of Econometrics, 64, 165-182.

Bourdieu, P. (1986). The forms of capital. In J. G. Richardson (Ed.), Handbook of theory and research for the sociology of education (pp. 241-258). Greenwood Press.

Bryan, M. L., \& Jenkins, S. P. (2016a). Multilevel modelling of country effects: A cautionary tale. European Sociological Review, 32(1), 3-22.

Bryan, M. L., \& Jenkins, S. P. (2016b). Multilevel modelling of country effects: A cautionary tale. Supplementary material. European Sociological Review, 32(1), 3-22.

Card, D. (1995). The wage curve: A review. Journal of Economic Literature, 33, 285-299. 
Coleman, J. S. (1988). Social capital in the creation of human capital. American Journal of Sociology, 94, 95-120.

Curtis, J. E., Baer, D. E., \& Grabb, E. G. (2001). Nations of joiners: Explaining voluntary association membership in democratic societies. American Sociological Review, 66(6), 783-805.

Damian, E. (2018). Formal volunteering in Europe: Evidence across nations and time. Cross-Cultural Research, 53(4), 1-25. https:// doi.org/10.1177/1069397118802228.

Delhey, J., \& Newton, K. (2005). Predicting cross-national levels of social trust: Global pattern or Nordic exceptionalism? European Sociological Review, 21(4), 311-328.

Deneulin, S., Nebel, M., \& Sagovsky, N. (Eds.). (2006). Transforming unjust structures. . Springer.

Eurostat. (2016). Methodological guidelines and description of 2015 EU-SILC target variables. European Commission.

Franzese, R. J. (2005). Empirical strategies for various manifestations of multilevel data. Political Analysis, 13, 330-346.

Freeman, R. B. (1997). Working for nothing: The supply of volunteer labour. Journal of Labour Economics, 15(1), 140-166.

Gil-Lacruz, A. I., \& Marcuello-Servos, C. (2013). Voluntary work in Europe: Comparative analysis among countries and welfare systems. Social Indicators Research, 114, 371-382.

Gil-Lacruz, A. I., Marcuello-Servos, C., \& Saz-Gil, M. I. (2016). Youth volunteering in countries in the European Union: Approximation to differences. Nonprofit and Voluntary Quarterly, 45(5), 971-991.

Gil-Lacruz, A. I., Marcuello-Servos, C., \& Saz-Gil, M. I. (2017). Individual and social factors in volunteering participation rates in Europe. Cross-Cultural Research, 51(5), 464-490.

Glanville, J. L., Paxton, P., \& Wang, Y. (2016). Social capital and generosity: A multilevel analysis. Nonprofit and Voluntary Sector Quarterly, 45(3), 526-547.

Hanushek, E. A. (1974). Efficient estimators for regressing regression coefficients. American Statistician, 28, 66-67.

Harris, B., Morris, A., Ascoygh, R. S., Chicoto, G. L., Elson, P. R., McLoughlin, J., Muukonen, M., Pospíšilová, T., Roka, K., Smith, D. H., Soteri-Proctor, A., Tumanova, A. S., \& Yu, P. (2016). History of associations and volunteering. In D. H. Smith, R. A. Stebbins, \& J. Grotz (Eds.), The Palgrave handbook of volunteering, civic participation, and nonprofit associations. (pp. 23-58). Palgrave Macmillan.

Hodgkinson, V. (1995). Key factors influencing caring, involvement, and community. In P. Schervish, V. Hodgkinson, M. Gates, \& Associates (Eds.), Care and community in modern society (pp. 21-50). Jossey-Bass.

Hustinx, L., von Essen, J., Haers, J., \& Mels, S. (Eds.). (2015). Religion and volunteering. Complex, contested and ambiguous relationships. . Springer.

International Labour Organization. (2011). Manual on the measurement of volunteer work.

Jusko, K. L., \& Shively, W. P. (2005). Applying a two-step strategy to the analysis of cross-national public opinion data. Political Analysis, 13, 327-344.

Kamerāde, D., Crotty, J., \& Ljubownikow, S. (2016). Civil liberties and volunteering in six former Soviet Union countries. Nonprofit and Voluntary Sector Quarterly, 45(6), 1150-1168.

Kedar, O., \& Shively, W. P. (2005). Introduction to the special issue. Political Analysis, 13, 297-300.

Kelley, J., \& De Graaf, N. D. (1997). National context, parental socialization, and religious belief: Results from 15 nations. American Sociological Review, 62, 639-659.

Lancee, B., \& Van de Werfhorst, H. G. (2012). Income inequality and participation: A comparison of 24 European countries. Social Science Research, 41, 1166-1178.

Layder, D. (1981). Structure, interaction and social theory. . Routledge.
Lewis, J. B., \& Linzer, D. A. (2005). Estimating regression models in which the dependent variable is based on estimates. Political Analysis, 13, 345-364.

McCarthy, J. D., \& Zald, M. N. (1977). Resource mobilization and social movements. American Journal of Sociology, 82, $1212-1241$.

Nambiar, S. (2013). Capabilities, conversion factors and institutions. Progress in Development Studies, 13(3), 221-230.

Nussbaum, M. C. (2000). Women and human development. The capabilities approach. . Cambridge University Press.

Plagnol, A. C., \& Huppert, F. A. (2009). Happy to help? Exploring the factors associated with variations in rates of volunteering across Europe. Social Indicators Research, 97, 157-176.

Putnam, R. D. (1993). Making democracy work. . Princeton University Press.

Putnam, R. D. (1995a). Bowling alone: America's declining social capital. Journal of Democracy, 6(1), 65-78.

Putnam, R. D. (1995b). Tuning in, tuning out: The strange disappearance of social capital in America. Political Science and Politics, 28(4), 664-683.

Ragin, C. C. (1998). Comments on "Social origins of civil society." VOLUNTAS: International Journal of Voluntary and Nonprofit Organizations, 9(3), 261-270.

Rothstein, B. (2001). Social capital in the social democratic welfare state. Politics \& Society, 29(2), 207-241.

Rothstein, B., \& Stolle, D. (2008). The state and social capital: An institutional theory of generalized trust. Comparative Politics, 40(4), 441-459.

Ruiter, S., \& De Graaf, N. D. (2006). National context, religiosity, and volunteering: Results from 53 countries. American Sociological Review, 717, 191-210.

Salamon, L. M. (1987). Partners in public service: The scope and theory of government-nonprofit relations. In W. W. Powell (Ed.), The nonprofit sector. A research handbook. (pp. 99-117). Yale University Press.

Salamon, L. M., \& Anheier, H. K. (1998). Social origins of civil society: Explaining the nonprofit sector cross-nationally. VOLUNTAS: International Journal of Voluntary and Nonprofit Organizations, 9(3), 213-248.

Salamon, L. M., \& Sokolowski, S. W. (2003). Institutional roots of volunteering. Toward a macro-structural theory of individual voluntary action. In P. Dekker \& L. Halman (Eds.), The value of volunteering. (pp. 71-90). Kluwer Academic.

Salamon, L. M., Sokolowski, S. W., \& Haddock, M. A. (2017). Explaining civil society development. . Johns Hopkins University Press.

Saxonhouse, G. R. (1976). Estimated parameters as dependent variables. American Economic Review, 66, 178-183.

Schröder, J., \& Neumayr, M. (2019). How inequality affects philanthropy: A systematic literature review. In Paper presented at the 48th Annual ARNOVA Conference, San Diego, CA, USA, November 21.

Sen, A. (1982). Equality of what? In Choice, welfare and measurement (pp. 353-369). Oxford University Press. (Reprinted from Tanner lectures on human values 1, by S. McMurrin, Ed., 1980, Cambridge University Press)

Sen, A. (1985). Commodities and capabilities. . North Holland.

Sen, A. (1992). Inequality reexamined. . Harvard University Press.

Sen, A. (1997). Human capital and human capabilities. World Development, 25(12), 1959-1961.

Steinberg, R., \& Young, D. R. (1998). A comment on Salamon and Anheier's "Social origins of civil society." VOLUNTAS: International Journal of Voluntary and Nonprofit Organizations, 9(3), 249-260.

Teorell, J., Kumlin, S., Dahlberg, S., Holmberg, S., Rothstein, B., Alvarado Pachon, N., \& Svensson, R. (2019). The quality of 
government OECD dataset (Version Jan19). University of Gothenburg: The Quality of Government Institute. https://doi. org/10.18157/qogoecdjan19

Uslaner, E. M. (2003). Trust, democracy and governance. Can government politics influence generalised trust? . Palgrave Macmillan.

Uslaner, E. M., \& Brown, M. (2005). Trust, inequality, and civic engagement. American Political Research, 33(6), 868-894.

Weisbrod, B. A. (1977). The voluntary nonprofit sector. . Heath.
Wilson, J., \& Musick, M. (1997). Who cares? Toward an integrated theory of voluntary work. American Sociological Review, 62, 694-713.

Wilson, J., \& Musick, M. (2008). Volunteers, a social profile. . Indiana University Press.

Publisher's Note Springer Nature remains neutral with regard to jurisdictional claims in published maps and institutional affiliations. 